\title{
Research Paper \\ A Comparison of the Effect of Positive Existential Therapy and Iranian-Islamic Positive Therapy on Affective Capital of Female Students with Social Anxiety
}

\author{
Sara Madadi Zavareh ${ }^{1}$, Mohsen Golparvar ${ }^{* 2}$, Asghar Aghaei $^{3}$ \\ 1. Ph.D. in Psychology, Isfahan (Khorasgan) Branch, Islamic Azad University, Isfahan, Iran
}

2. Associate Professor, Department of Psychology, Isfahan (Khorasgan) Branch, Islamic Azad University, Isfahan, Iran

3. Professor, Department of Psychology, Isfahan (Khorasgan) Branch, Islamic Azad University, Isfahan, Iran

Citation: Madadi Zavareh S, Golparvar M, Aghaei A. A comparison of the effect of positive existential therapy and iranian-islamic positive therapy on affective capital of female students with social anxiety. Quarterly Journal of Child Mental Health. 2019; 6(3): 112-125.

http://dx.doi.org/10.29252/jcmh.6.3.11

A R T I C L E I N F O

Keywords:

Social anxiety,

affective capital,

positive existential

therapy,

Iranian-Islamic positive

treatment,

female students

Received: 19 Jul 2018

Accepted: 13 Dec 2018

Available: 9 Nov 2019

\section{A B S T R A C T}

Background and Purpose: Affective capital is one of the most new constructs that can substantially help female students to overcome their problems. This study was conducted to compare the effect of positive existential therapy and Iranian-Islamic positive therapy on the affective capital of female students with social anxiety.

Method: This study was a semi-experimental research with three group two stage (pre-test and posttest) design. The sample consisted of forty five 15-18 year old female students with social anxiety studying at the $2^{\text {nd }}$ grade of secondary school in Ardestan in 2017. They were randomly assigned to three groups (two experimental and one control group). Social anxiety questionnaire (Connor et al., 2000) and affective capital questionnaire (Golparvar, 2016) were used to measure the dependent variables at the pretest and post-test. The positive existential therapy group received 10 sessions of treatment, Iranian-Islamic positive therapy group received 11 sessions of treatment, and the control group received no treatment. The data were analyzed by analysis of covariance.

Results: The results showed that there was significant difference in the pretest and posttest score of positive existential therapy group, Iranian-Islamic positive therapy group, and control group in terms of affective capital and its three components; i.e. positive affection, feeling of energy, and happiness $(\mathrm{p}<0.001)$.

Conclusion: Based on the findings of this study, it seems that because of helping the girls with social anxiety to cope with their anxiety, positive existential therapy and Iranian-Islamic positive treatment can improve the affective capital of these girls.

\footnotetext{
* Corresponding author: Mohsen Golparvar, Associate Professor, Department of Psychology, Isfahan (Khorasgan) Branch, Islamic Azad University, Isfahan, Iran.

E-mail addresses: Drmgolparvar@gmail.com
}

2476-5740/ (C) 2019 The Authors. This is an open access article under the CC BY-NC-ND license (https://creativecommons.org/licenses/by-nc-nd/3.0/). 


\section{مقايسه تأثير درمان مثبتنكرى وجود درا و درمان مثبتنكر ايرانى - اسلامى بر سرمايه عاطفى

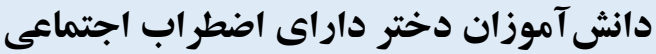

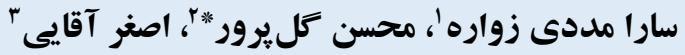

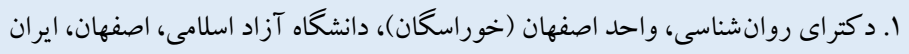

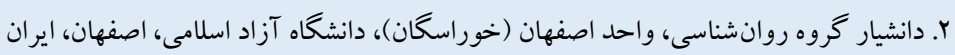

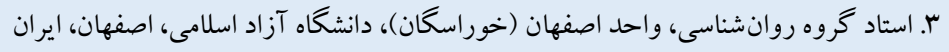

جكيده

زمينه و هدف: سرمايه عاطفى يكى از جديدترين سـازهمايى اسـت كه مى تواند به دانش آموزان دختر براى غلبه بر مشكلات خود، كمك

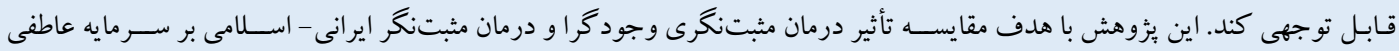
دانش آموزان دختر داراى اضطر اب اجتماعى انجام شد.

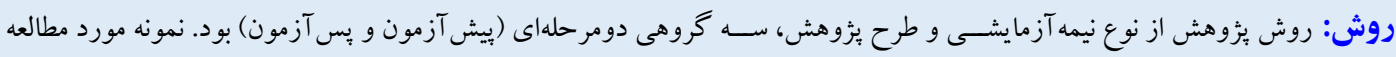

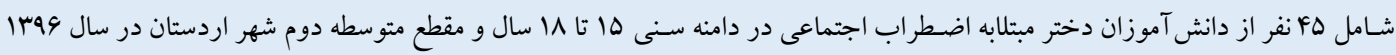

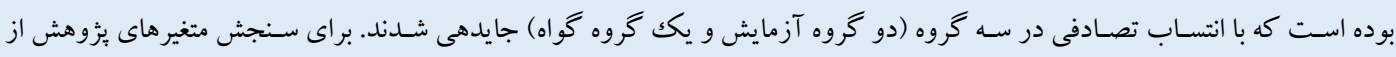

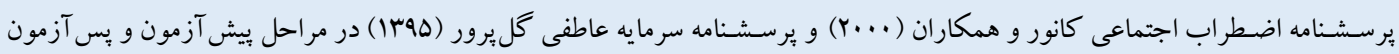

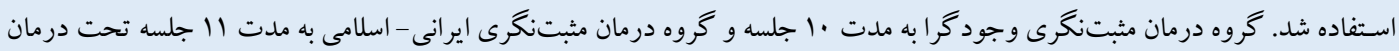

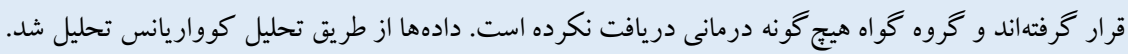

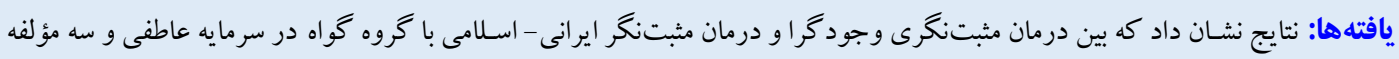

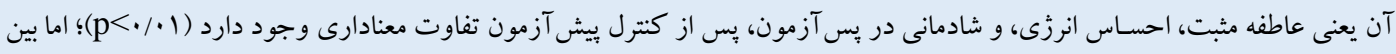

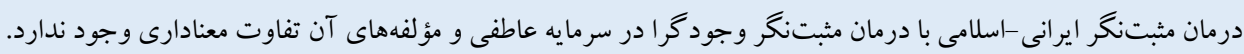

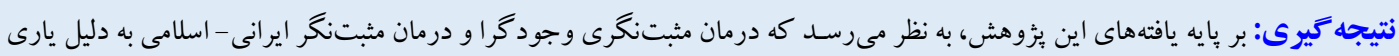

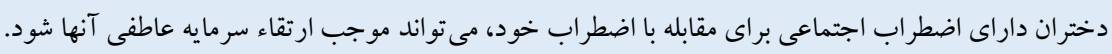

مشخصات مقاله

كليدوازهها:

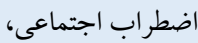

سرمايه عاطفى،

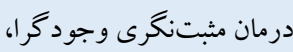
درمان مثبتنخر ايرانى - اسلامى، وردك، دانش آموزان دختر
دريافت شده: PV/F/ P Q منتشر شده:

* نويسنده مسئول: محسن گل يرور، دانشيار گروه روانشناسى، واحد اصفهان (خوراسگان)، دانشكاه آزاد اسلامى، اصفهان، ايران.

راياناه: Drmgolparvar@gmail.com

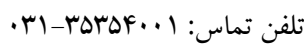


روانشـناسـى مثبتنكر روى آوردى متمر كز بر افزايش توانايىهاو

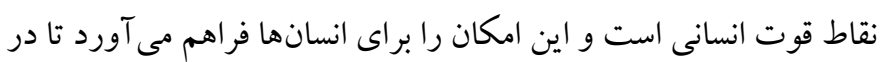

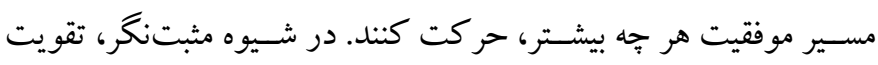

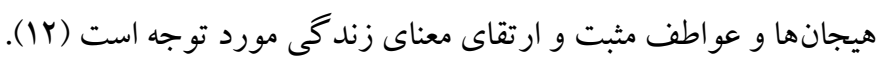

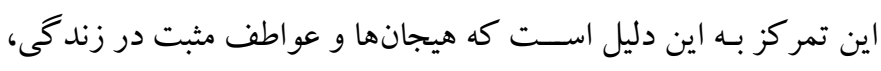

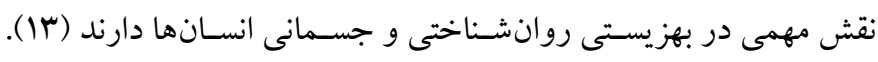

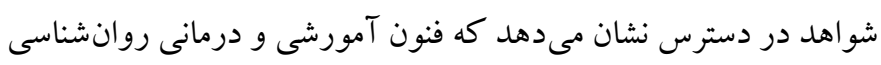

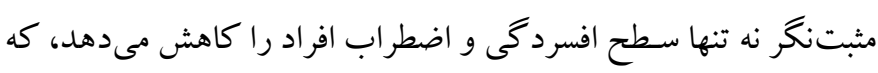

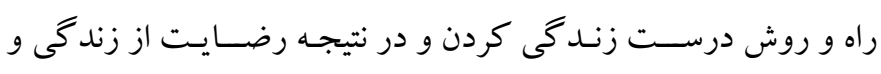

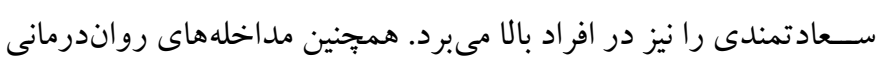

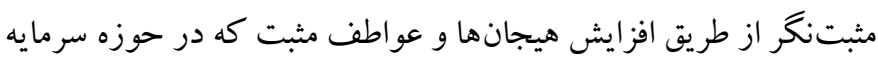

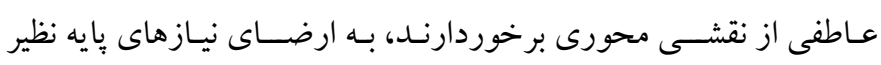

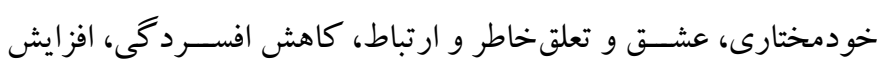

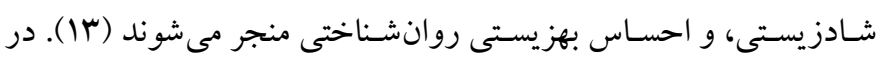

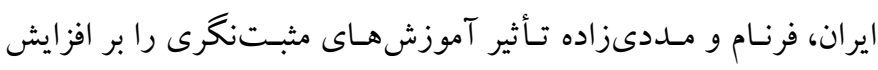

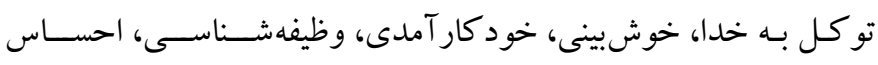

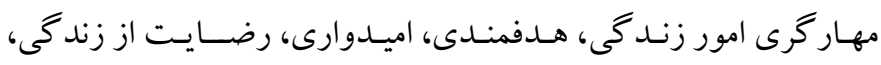

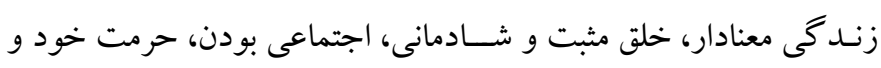

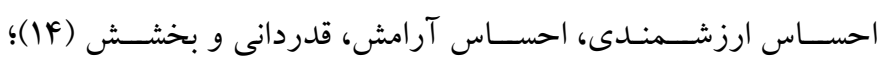

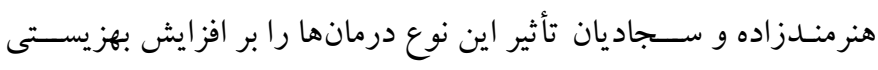
روانشـناختى، تابآورى، و شادزيستى (1))؛ و نوفرستى و همكاران نيز

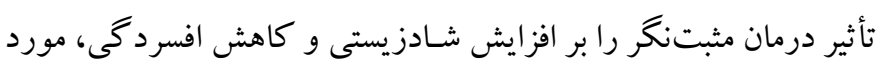

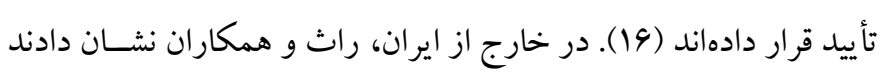

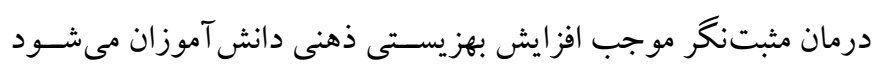

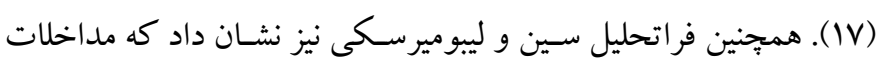

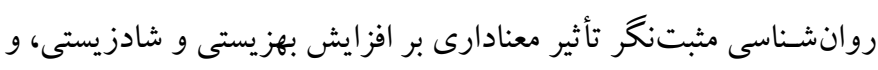

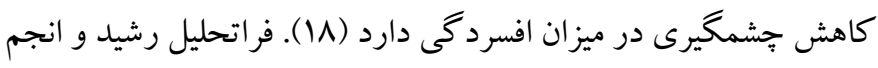

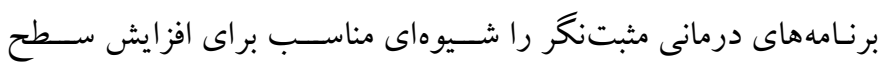

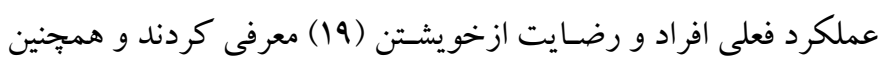

\section{Feeling of energy}

6. Happiness

7. Positive psychology interventions
مقلهمه

اختلال اضـطر اب اجتماعى '، نشـانگان عصسبى - روانشـناختى ييجيده و جندوجهى است كه در طبقهبندى آمارى و تشخيصى اختلالهاى روانى طبقه مستقلى از اختلال ها را تشكيل مى دهد. اين اختلال با ترس شديد از مورد ارزيـابى قرار كرفتن در موقعيـتهـاى اجتماعى يا موقعيتهايى كه فرد در حال انجام عمل يا فعاليتى خاص اسـت، قابل تشـخيص است (1). افر اد مبتلابه اين اختلال تقريباً هميشه نشانهاى اضطراب نظير ضربات قلب

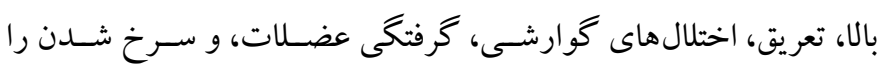
تجربه مى كنند (Y و r). مطالعات همه كيرشــناســى نشــان داده شــيوع اضــطر اب اجتمـاعى در جمعيت عمومى در طول عمر داراى دامنهاى از

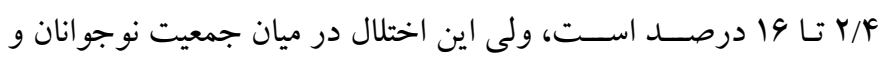
بالأخص نوجوانان دختر با شـيوع سا درصسـى شـايع تر از ديخر گروهها اسـت (f)، ه و 9). نو جوانان داراى اضطراب اجتماعى، نسبت به همسالان

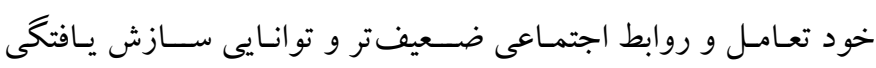
يايينترى دارند (Vو ( )، بهطورى كه منجر به مشـكلاتى در زمينه روابط اجتماعى و رشــد شـغلى و تحصـيلى مى شــود (9). شـوا اهد حاصـل از مطالعات نشـان مى دهد دانش آموزان داراى اضـطر اب اجتماعى اغلب به دليل افسردكى و احساس ضعف در حرمت خود و خود ارزشمندى (1) و 9) در زمينه هاى احسـاس نشـاط و انرزى، عاطفه مثبت و شـادمانى كه در صورتبندىهاى نوين به لحاظ نظرى تحت عنو ان سرمايه عاطفى “ّمطرح شــده اسـت ( •(1)، نيازمند يارى و كمكك هسـتند. سـرمايه عاطفى از نظر تعريف، وضــعيتى از نشـاط و انرزى عاطفى مثبت درونى قابل هدايت و

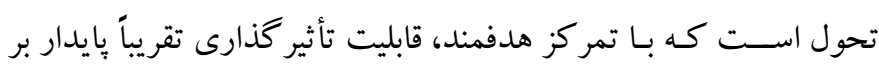

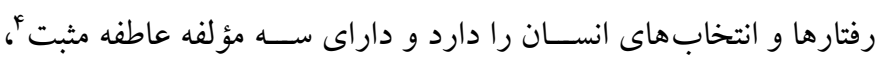
احساس انرزىه، و شادمانى هاست ( •(1). در سالهاى اخير نيز مداخلههاى روانشناسى مثبتنگر \در كنار درمانهاى ديكر از جمله درمان شناختى، درمان شــاختى - رفتارى، درمان مواجههســازى، و آموزش مهارتهاى اجتماعى براى كمكك به نوجوانان داراى اضطراب اجتماعى، مورد توجه يثزوهشخران و درمانكران قرار كرفته است (11).

1. Social anxiety disorder

2. Diagnostic and Statistical Manual of Mental Disorders

3. Affective capital

4. Positive affect 
ضعف در اين نوجوانان به سوى تو انمندى ها و معانى مثبت و عميقتر در

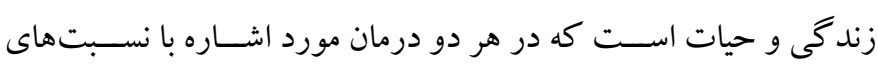

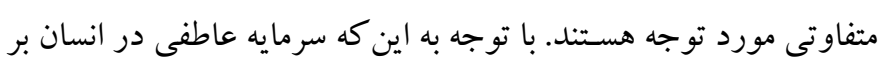

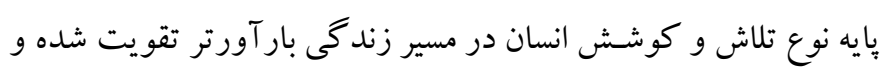

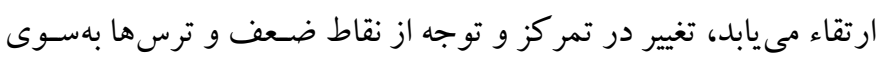

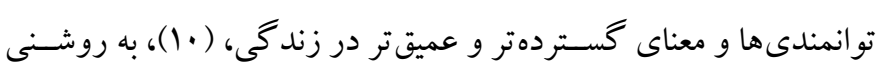

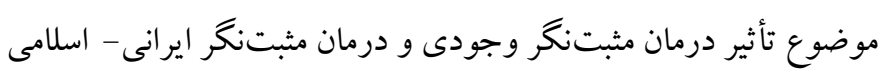
را كه در يزوهش حاضر محوريت دارد، برجسته مى سازد.

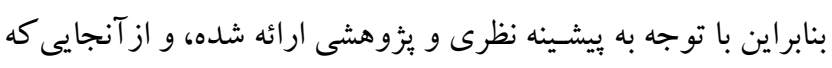
با وجود جستجوى مكرر نويسند گان اين مقاله، آن طور كه شايسته است،

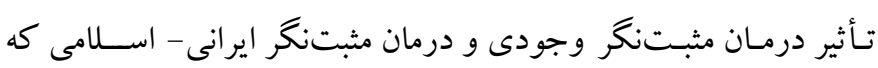

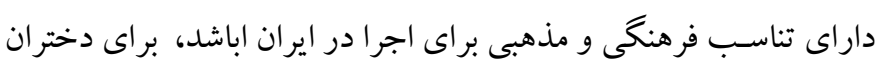

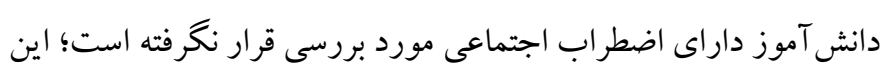

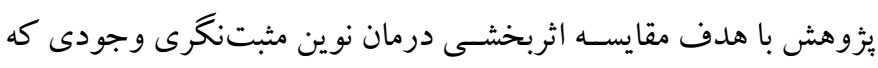

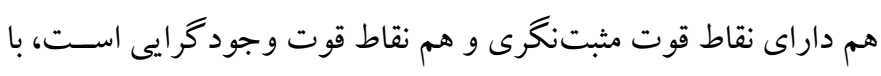

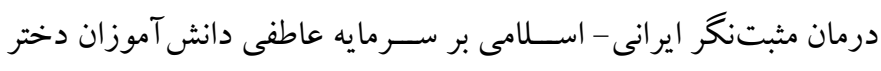

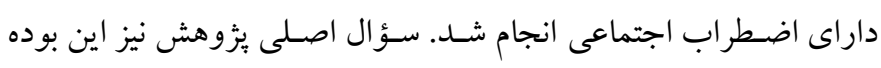

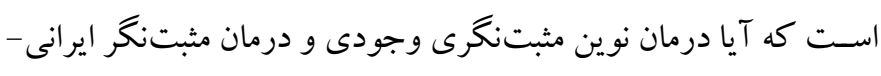

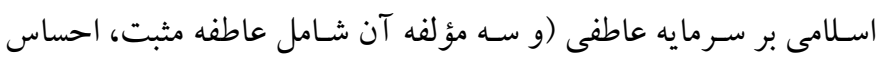

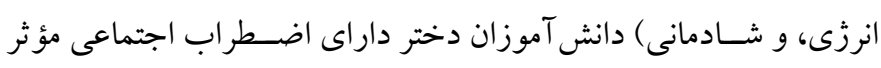

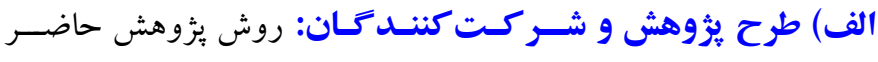

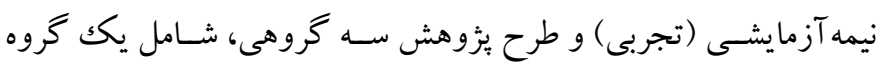

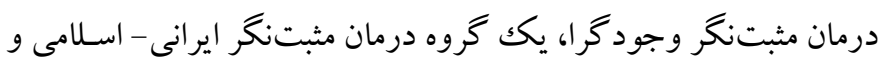

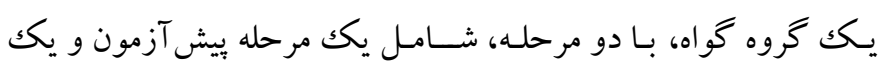

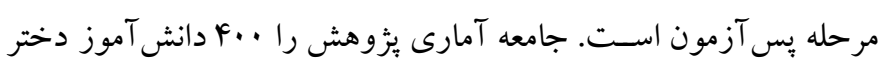

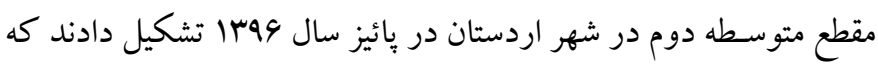

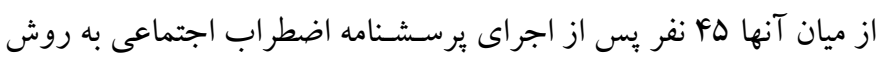

مطالعه سـليخمن و همكاران نيز نشـان دادند كه مداخله مثبتنكر موجب افزايش نشاط و شادمانى و كاهش علايم افسردگى مى شود ( (Y).

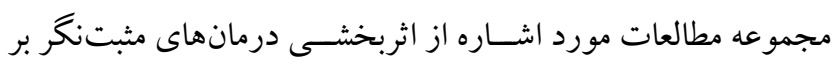

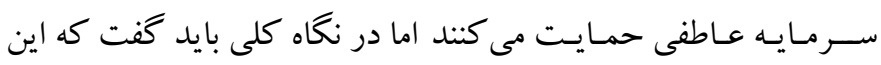

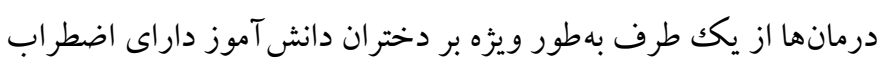

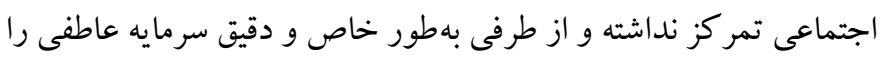

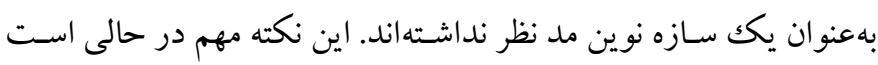

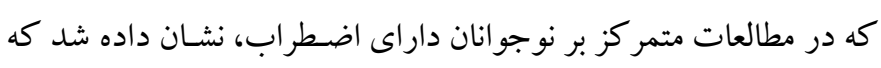

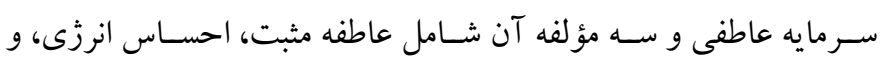

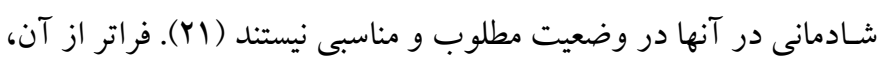

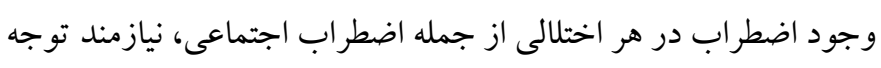

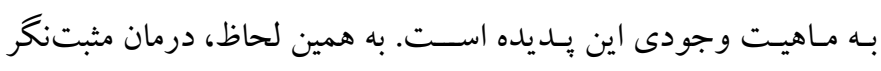

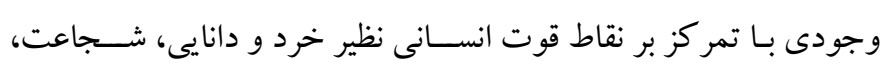

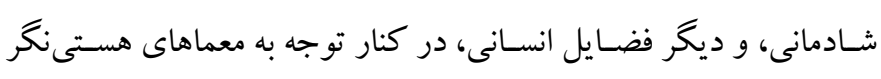

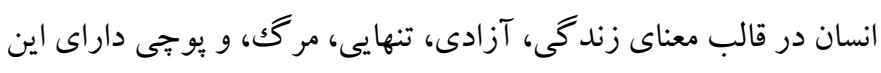

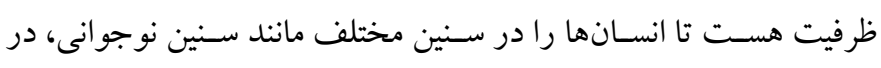
مسير رهايى از ترسها و نكخرانىها يارى كرده و از اين طريق بسـترسـاز

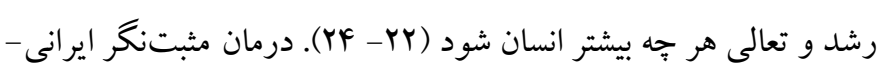

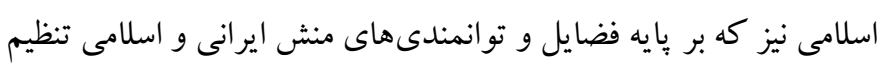

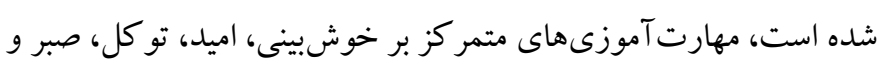

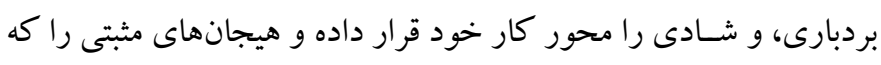

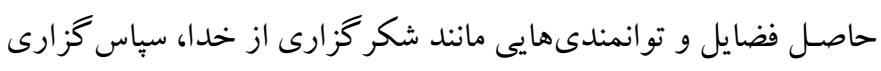

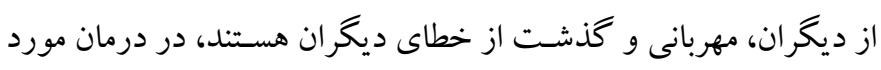

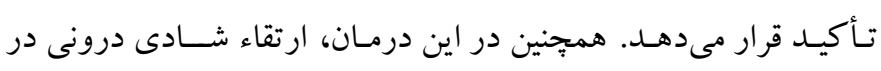

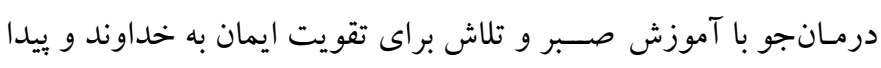

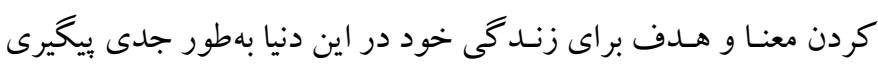
مىشود (YD). با توجه به آنجه درباره دو روى آورد درمانى مورد استفاده

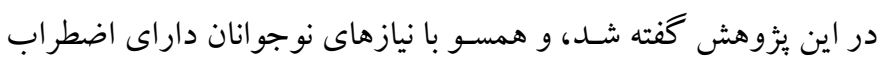

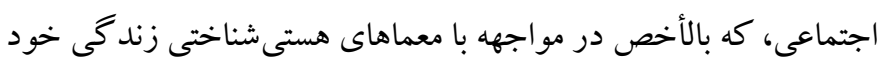

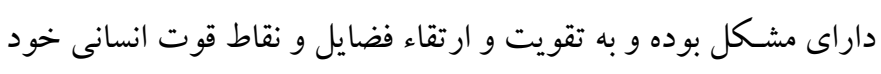

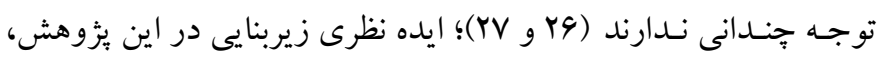

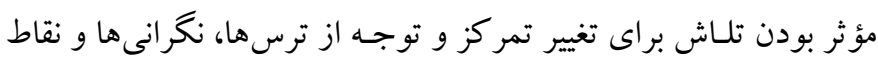


درمـانهاى روانيزشــكى و يا درمان روانشــناختى موازى، و غيبت دو جلسه و يا بيشتر در جلسات درمان بود. در نهايت افراد نمونه انتخاب شده

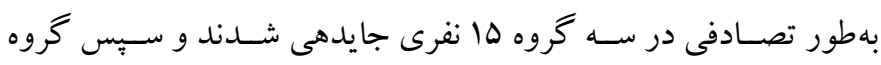

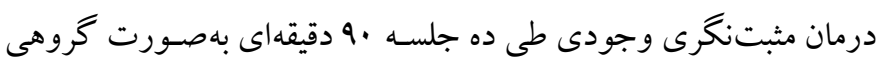
و هر هفته يكك بار، و گروه درمان مثبتنگرى ايرانى - اسـلامى طى يازده جلسـهـ •9 دقيقهاى بهصسورت كروهى و هر هفته يك بار، تحت درمان قرار گر فتند. ويثز گى هاى جمعيت شـناختى سه گروه يثروهش در جدول

ارائه شده است.
نمونه كيرى هدفمند' انتخاب شـدند. با توجه به اين كه ملاكك اصلى ورود به مطالعه داشــتن اضــطر اب اجتماعى در نقطه برش ••أو بالاتر بود و با

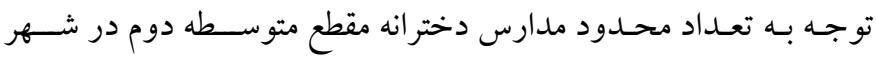
اردستان، بهجاى نمونه گيرى خوشهاى از نمونه گيرى هدفمند استفاده شد.

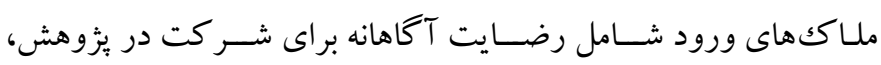
تحصــيل در مقطع متوســـه اول، ابتلا به اضــطر اب اجتماعى بر اســاس مصاحبه و اجراى يرسشنامه اضطراب اجتماعى كانور؛ و معيارهاى خروج نيز شــامـل عـدم تمـايـل بـه ادامـه درمـان، تحــ درمـان بودن از طريق

جدول 1: ويز كى هاى جمعيتشناختى درمان مثبتنكرى وجودى، درمان مثبتنكر ايرانى- اسلامى و كروه كواه (هر كروه 10 نفر)

\begin{tabular}{|c|c|c|c|c|}
\hline كروه مثبتنكر ايرانى - اسلامى & كروه مثبتنكر وجودى & كروه كواه & \multirow{2}{*}{ زير كروههاى متغير } & \multirow{2}{*}{ 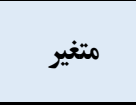 } \\
\hline فراوانى (درصد فراوانى) & فراوانى (درصد فراوانى) & فراوانى (درصد فراوانى) & & \\
\hline$(\gamma / \Gamma / \Gamma) \Delta$ & $(\% / \Gamma / \Gamma) \Delta$ & $(\% / \Delta \Gamma / \Gamma) \wedge$ & يايه دهم & \multirow{3}{*}{ بايه تحصيلى } \\
\hline$(\% \cdot \% \cdot)^{4}$ & $(\% \cdot \cdot)^{4}$ & $(\% / \Gamma / \Gamma) \Delta$ & بايه يازدهم & \\
\hline$(/ / Y G / V) F$ & $(/ r q / V) F$ & $(\% / r / \Gamma) r$ & يايه دوازدهم & \\
\hline$(/ Y G / V) F$ & $(1.9 / \mathrm{V}) 1$ & $(\% I r / r) r$ & 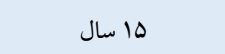 & \multirow{4}{*}{ 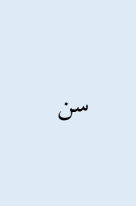 } \\
\hline ( & D & $(\%$ Y $/ V) F$ & 19 19 سال & \\
\hline$(\% / r / r) r$ & ( - ( & $(\% \& q / V) \vee$ & V lV & \\
\hline$(\%$ Y $/ V) F$ & $(\%$ Y $/ V) F$ & $(\% / r / r) r$ & 11 ال سال & \\
\hline D D & D D (Tس/T//\%) & $(\%$ Y $/ \mathrm{V}) F$ & 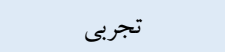 & \multirow{3}{*}{ رشته تحصيلى } \\
\hline$(\% . \$ 9 / 99) \mathrm{V}$ & D D & $(/ \% 9 / 9) V$ & انسانى & \\
\hline$(\% / r \cdot) r$ & D D & $(/$ Y $q / V) F$ & 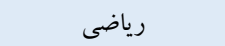 & \\
\hline
\end{tabular}

استفاده شد. روايى سازه اين يرسشنامه در مقايسه نتايج اين آزمون در دو

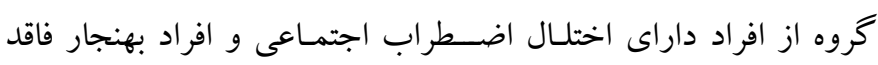
تشخيص روانيزشكى بررسى شد كه تفاوت معنادارى با هم نشان دادند.

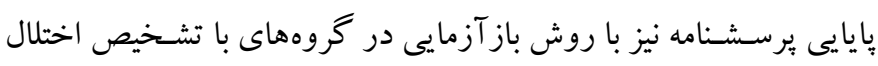

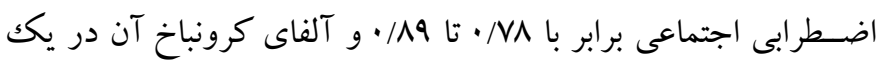

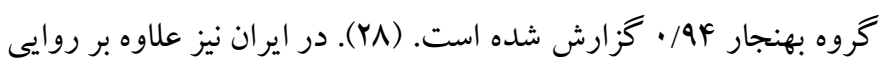

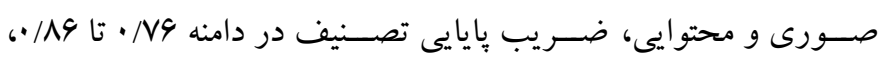
ضـريب اسـييرمن - براون برابر با ه| • • و ضريب آلفاى كرونباخ در دامنه

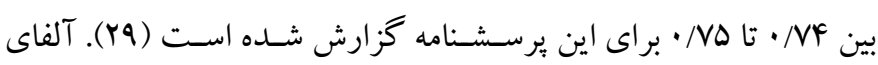
كرونباخ اين برسشنامه در يثوهش حاضر برابر با 9/ • به دست آمد.

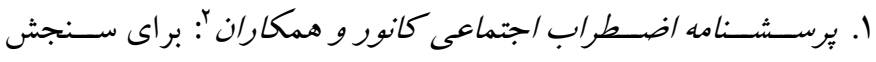
اضطراب اجتماعى از برسشنامه IV سؤالى كانور و همكاران كه در سال . . . . . . . . . اسـت، استفاده شد (YN). اين برسشنامه در يثزوهش حاضر براى تشخيص دانش آموزان دختر داراى اضــطراب اجتمـاعى در آغـاز مطـالعـه مورد

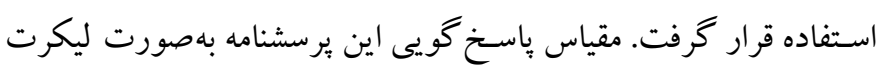

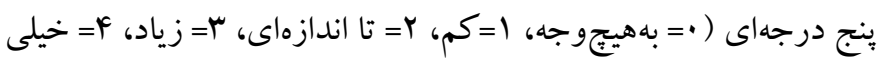
زياد) اسـت. در تفسـير نمرات، نقطه برش ·• با كارايى دقت تشـخص مطلوب، ·^ درصسـد افراد مبتلابه اضـطراب اجتماعى را از افراد غيرمبتلا متمايز مى كند (Yq). در مطالعه حاضــر نقطه برش ·F براى كزينش اوليه 
نظر شـش داور متخصــص روانشـــــاس فعـال در حوزه درمـانهـاى

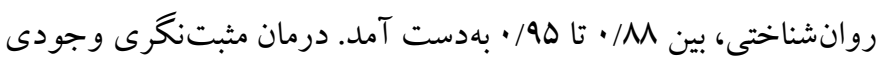

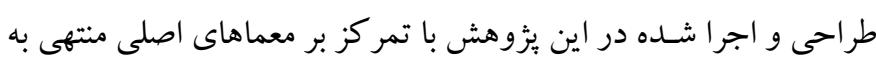

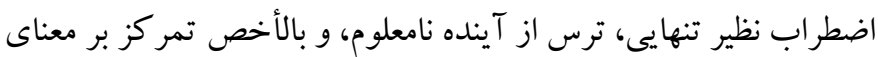

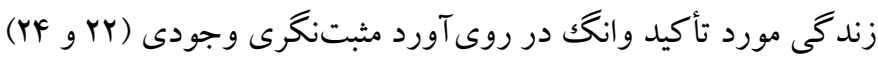

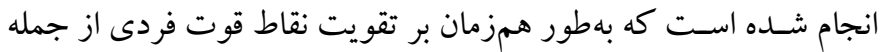
دانايى و خرد، اعتدال، شـجاعت، عدالتجويى، انسـانيت، و شكوفايى و

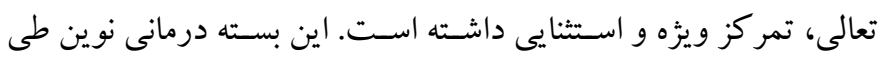

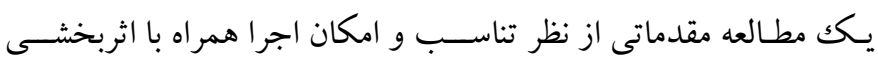

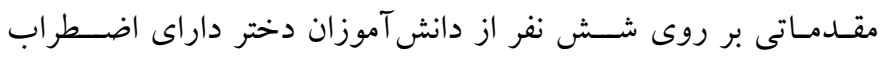

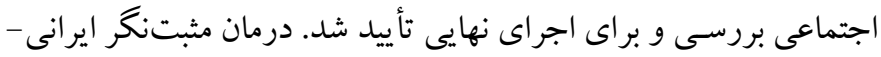

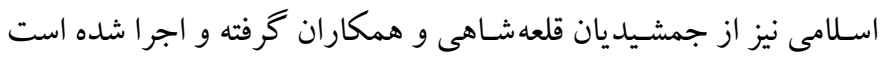

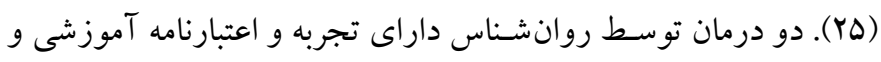

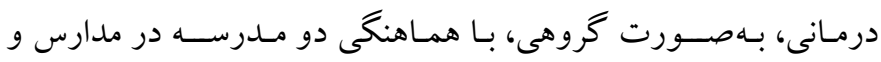

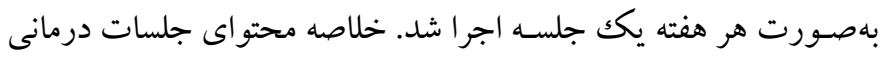

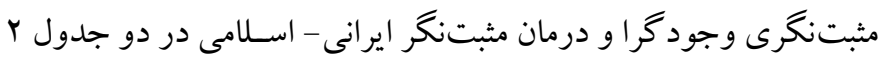
و بارائه شده است. r. برسـشـامه سـرما يه عاطفى كل يرور': براى سـنجش سـرمايه عاطفى،

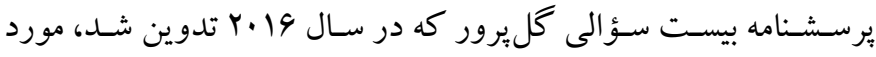

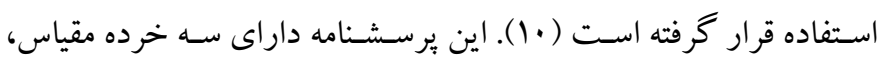
عاطفه مثبت (ده سـؤال)، احساس انرزى (ه سؤال)، و شادمانى (ه سؤال)

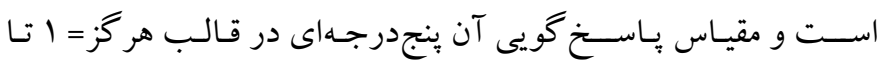

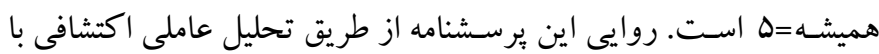
جرخش از نوع واريماكس بررسـى، و آلفاى كرونباخ آن در دامنه بين

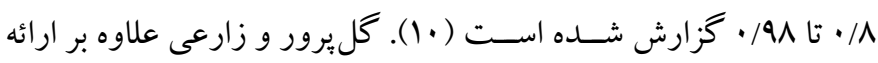
شو اهد روايى همخر اى اين برسشنامه بر مبناى همبستخى امتيازات حاصل

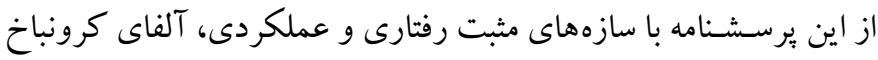

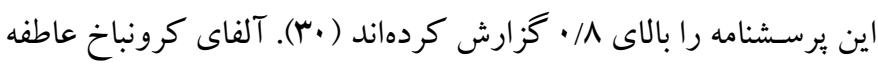

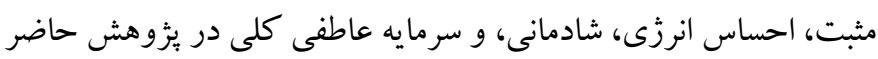

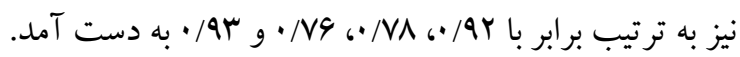

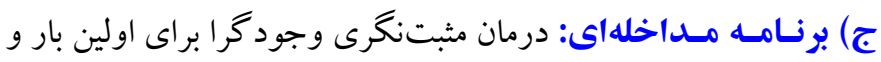

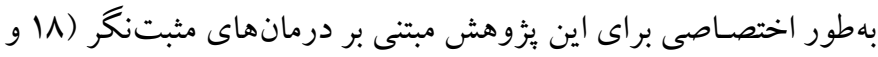

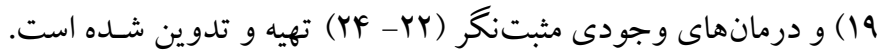

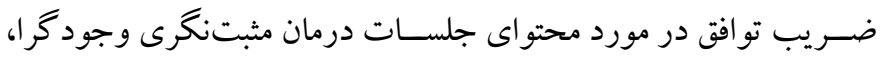
ساختار درمان، كفايت درمان، و مناسب بودن طول زمان درمان مردان بر اساس

جدول r: جلسات درمان مثبتنكرى وجود

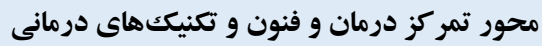

\section{جلسات درمان}

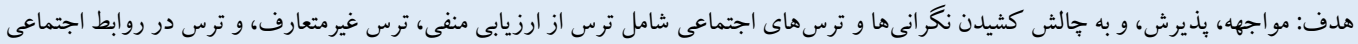

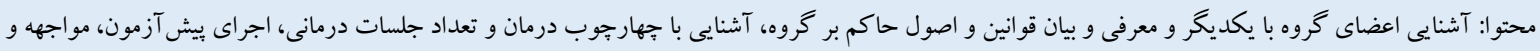

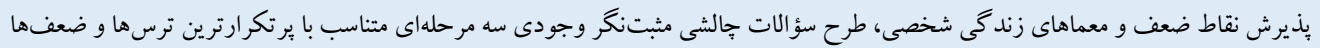

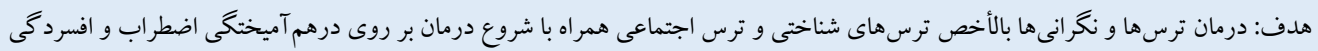

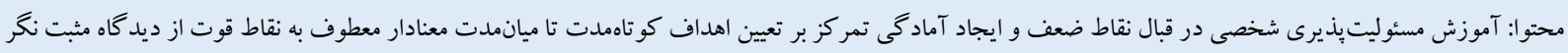

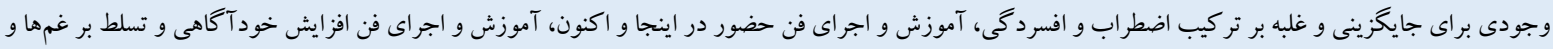

$$
\text { ترس هاى خود }
$$

هدف: درمان خلق تحريكك يذير و درهم آميختىى عاطفى و شناختى با تمركز بر باور به نقاط قوت و توانايىها و تعهد به اقدام و به كار بردن اهداف جديد براى مقابله با اضطراب

$$
\text { در موقعيتهاى اجتماعى }
$$

محتوا: تعيين توانمندىها و نقاط قوت انسانى -خردمندى و عدالت، آموزش و اجراى فن باور به اهداف جديد و نقاط قوت در موقعيتهاى اجتماعى، آموزش و اجراى فن تعهد

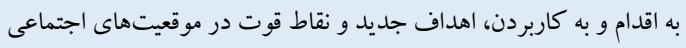

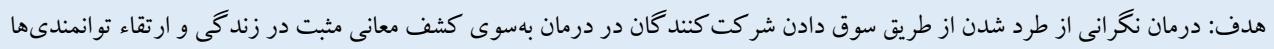




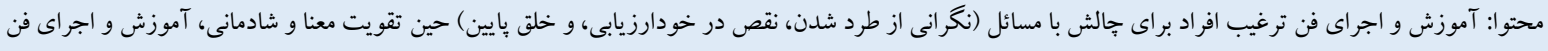

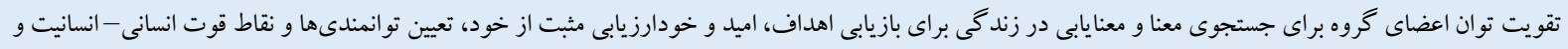

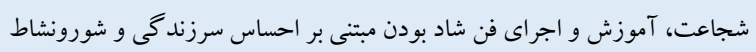

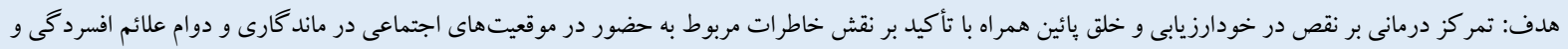

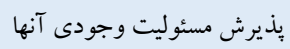

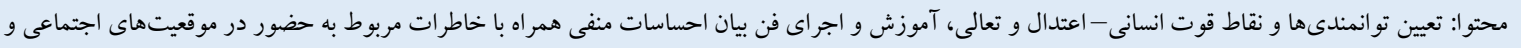

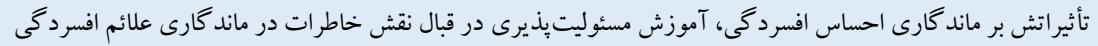

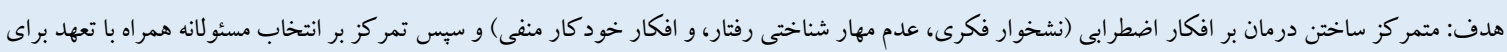

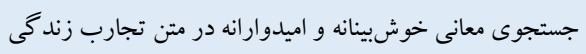

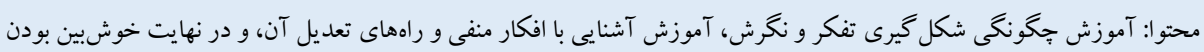

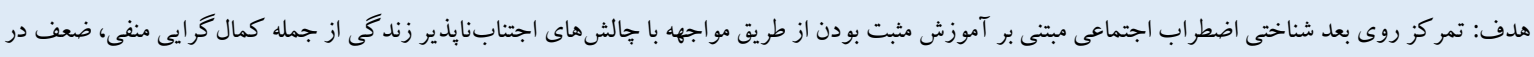

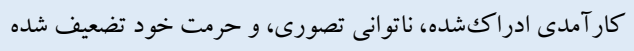

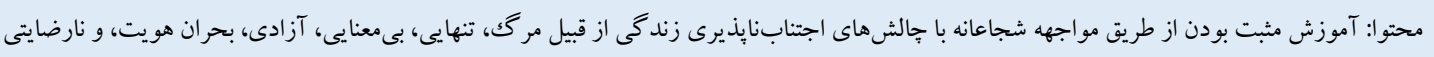

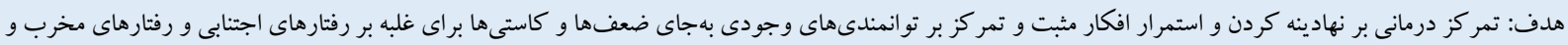
نا كار آمدى هاى تحصيلى

محتوا: آموزش نهادينه كردن راهبردهاى تفكر مثبت و خوشينى در زندگى، آموزش و اجراى فن استمرار در تمرين افكار مثبت و خوشبينى، تمرين كنار آمدن و سازش با نا

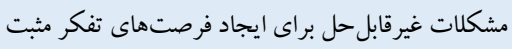

هدف: ايجاد رابطه مثبت و بهينه با خود و ديخر ان و ارتقاء روابط اجتماعى به واسطه شوخطبى در راستاى مشكلات معطوف به رفتارهاى گرايشى اجبارى و رفتار منفعلانه،

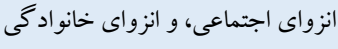

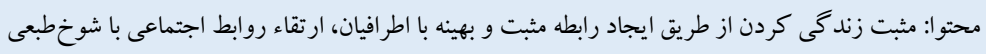

هدف: جمع بندى و يكيار جهسازى اهداف درمانى

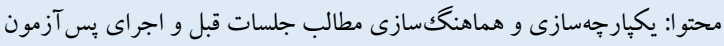

\section{جدول "ّ: جلسات درمان مثبتنكرى ايرانى -اسلامى}

\section{محور تمركز درمان و فنون و كنيككهاى درمانى}

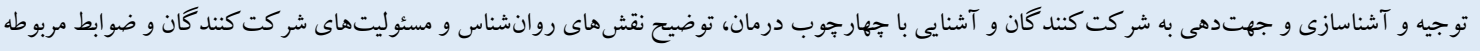

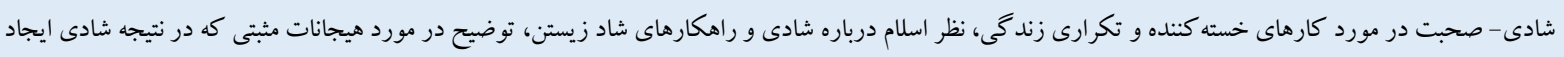

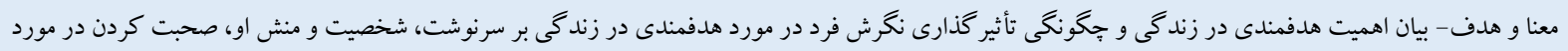

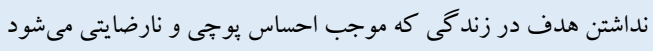

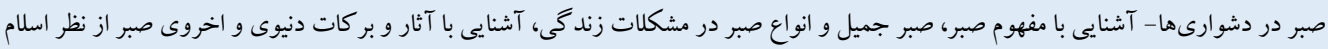

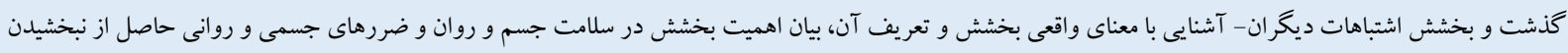

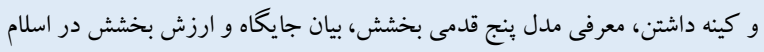

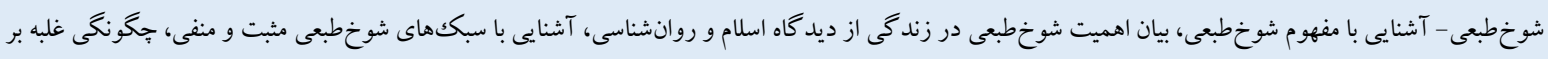

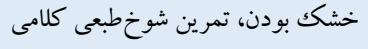

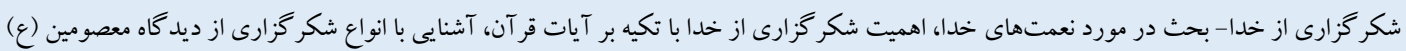

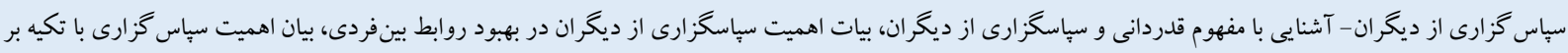

$$
\text { آيات و احاديث و روايات، آشنايى با مراحل نحوه قدردانى از ديخر ديكران }
$$

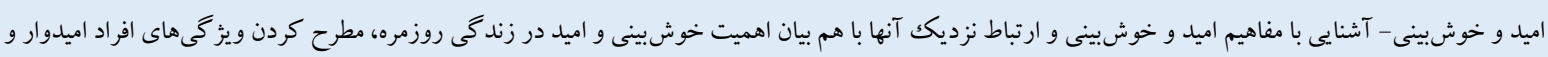

$$
\text { خوشبين، بيان اهميت حسن ظن به خدا با ذكر آيات و احاديث }
$$


از يزوهش، اطلاعرسـانى كامل در مورد يزوهش، كسـبـ رضـايتنامه كتبى، و استفاده از دادهها فقط در راستاى اهداف يزوهش، به طور كامل

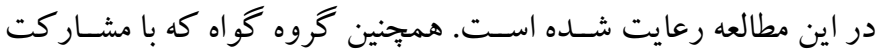
خود اجراى اين يُزوهش را همراهى كردنـد، در بـايسان دوره اجراى

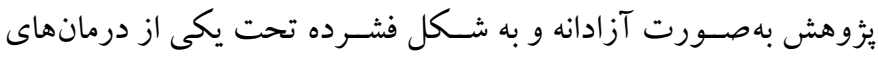
مثبتنخرى وجودى و يا مثبتنخرى ايرانى - اسلامى قرار گرفتند.

يافتهها در جدول F آمارههاى توصيفى سـرمايه عاطفى و مؤلفه هاى آن همراه با آزمون كالمو گروف-اسـميرنف براى بررسـى نرمال بودن دادهها براى

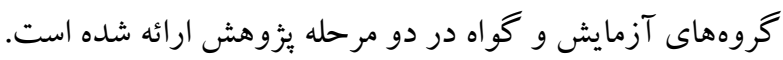

د) روش اجرا: روند اجر ایى يزوهش به اين صسورت بود كه ابتدا جهت

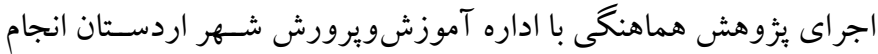

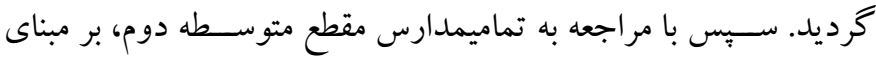

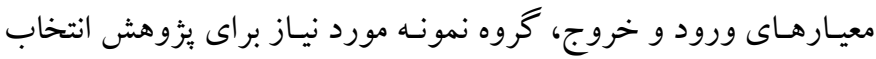

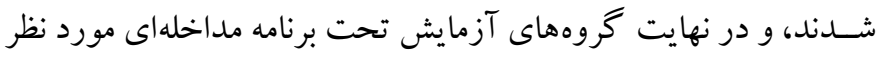

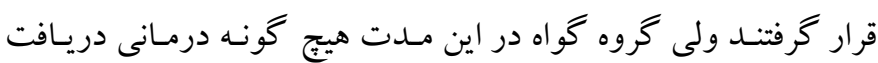

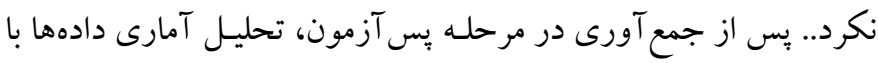
استفاده از نرمافزار SPSS در دو سطح آمار تو صيفى و استنباطى انجام شـده اسـت. در ســطح توصـيفى ميانگين و انحر اف معيار و در ســطح

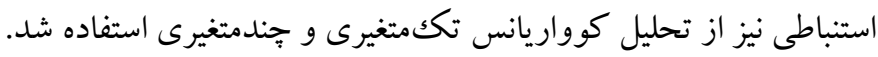

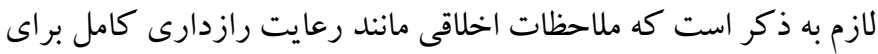
تكك تكك شر كت كنند كان، داشتن آزادى و اختيار كامل براى كناره گيرى

جدول ع: آمارههاى توصيفى به تفكيك سه كروه بزوهش و در دو مرحله بيش آزمون و يس آزمون (تعداد: 0ع نفر)

\begin{tabular}{|c|c|c|c|c|c|c|c|c|c|c|}
\hline \multirow{2}{*}{ كولموكروف- } & \multicolumn{2}{|c|}{ كروه كواه } & \multirow{2}{*}{ اسميرنف (سطح كروف- } & \multicolumn{2}{|c|}{ ايرانى - اسلامى مثبت نكر } & \multirow{2}{*}{ اسميرنف (سطح مولم } & \multicolumn{2}{|c|}{ 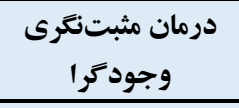 } & \multirow{2}{*}{ مرحله } & \multirow{2}{*}{ متغير } \\
\hline & انحر اف معيار & ميانكين & & انحراف & ميانكين & & انحراف & ميانكين & & \\
\hline$(\cdot / r) \cdot / 1 \Delta$ & $1 . / 90$ & $Y F / F V$ & $(\cdot / r) \cdot / 1 \cdot r$ & $\Delta / Y \Lambda$ & $r \cdot / r$ & $(\cdot / r) \cdot / I r$ & $9 / \pi$ & rQ/Tr & ييش آزمون & \multirow{2}{*}{ عاطفه مثبت } \\
\hline$(\cdot / Y) \cdot / 19$ & $\| / r \mid$ & TF/qR & $(\cdot / r) \cdot / 19$ & $8 / \cdot 1$ & YN/G & $(\cdot / r) \cdot / 10$ & $\Delta / r_{1}$ & M/A & پِس آزمون & \\
\hline$(\cdot / \cdot \Lambda) \cdot / r I$ & F/AT & $I T / Y$ & $(\cdot / Y) \cdot / 19$ & $r / \Delta q$ & $1 \cdot / r$ & $(\cdot / r) \cdot / r$ & ه ט/r & س & ييش آزمون & \multirow{2}{*}{ احساس انرزى } \\
\hline$(\cdot / Y) \cdot / I V$ & $\Delta / \cdot r$ & $\mid r / F$ & $(\cdot / r) \cdot / I V$ & r/r & $\mid f / \cdot V$ & $(\cdot / / r) \cdot / r$ & $r / 90$ & $I V / r$ & پِ آزمون & \\
\hline$(\cdot / 14) \cdot / 19$ & $F / \& V$ & $\mid F / A V$ & $(\cdot / \cdot 9) \cdot / r r$ & r/vN & $11 / r$ & $(\cdot / \cdot F) \cdot / r r$ & $r / r F$ & $I r / V r$ & يِش آزمون & \multirow{2}{*}{ شادمانى } \\
\hline$(\cdot / Y) \cdot / 11$ & $\Delta / Y I$ & $\mid F / A 9$ & $(\cdot / \cdot 1) \cdot / Y \mid$ & ג ו ג & $10 / r$ & $(\cdot / Y) \cdot / 19$ & $r / r q$ & IV/ar & پِ آزمون & \\
\hline$(\cdot / Y) \cdot / \Lambda$ & IN/YF & $\Delta 1 / \Delta r$ & $(\cdot / r) \cdot / r$ & $1 \cdot / \wedge \Delta$ & $F 1 / 9$ & $(\cdot / Y) \cdot / \Lambda$ & $11 / \Delta$ & $\Delta \cdot / f$ & ييش آزمون & \multirow{2}{*}{ سرمايه عاطفى كلى } \\
\hline$(\cdot / Y) \cdot / 19$ & $1 N / 9 V$ & $\Delta T / Y$ & $(\cdot / \cdot \Delta) \cdot / r r$ & १/१९ & $\Delta V / A V$ & $(\cdot / 10) \cdot / 19$ & $9 / 91$ & 9N/9r & يس آزمون & \\
\hline
\end{tabular}

نيز غيرمعنادار اسـت، به اين معنى كه مفروضـه نرمال بودن دادهها رعايت

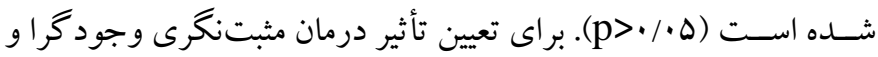

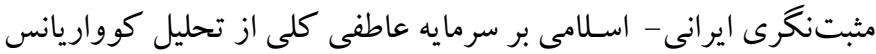

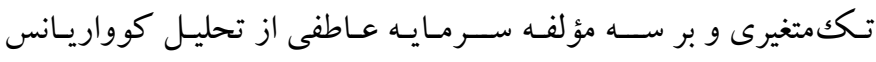

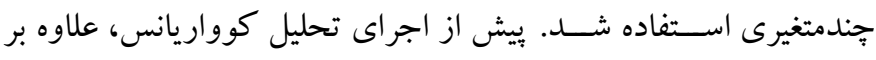

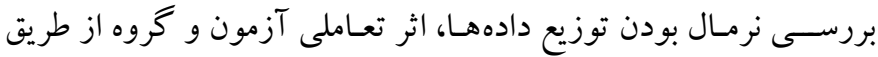

همـانطور كـه در جـدول ب مشــاهـده مى شــود، تغييرات از مرحله بيش آزمون به مرحله بِ آزمون در هر سـه مؤلفه عاطفه مثبت، احسـاس انرزى، و شـادمانى همراه با ســرمايه عاطفى كلى در هر دو گروه درمان

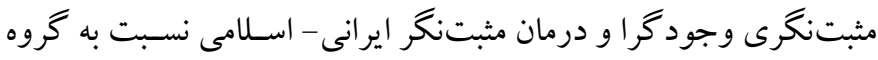

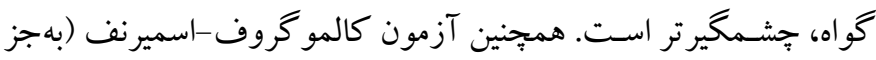

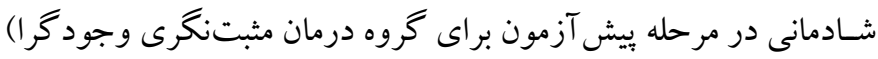


كوواريانس متغيرهاى وابسـته در ميان سـه گروه برابر اسـت (AF)

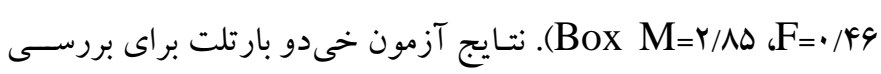
كرويت يا رابطه بين مؤلفههاى سرمايه عاطفى نشان داد كه رابطه بين اين

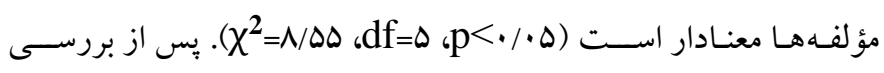
بيشفرض هـاى تحليـل كوواريـانس (تكك متغيرى و جن متغيرى)، براى تأثير برنامه بر سرمايه عاطفى كلى، تحليل كوواريانس تكك متغيرى انجام شد كه نتايج آن در جدول ها ارائه شده است.

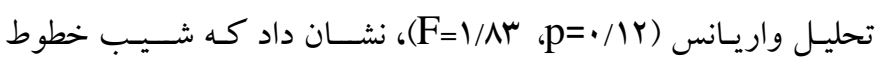

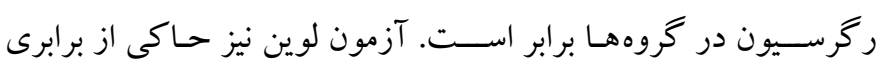
واريانس خطا (آماره F لوين به ترتيب براى عاطفه مثبت، احساس انرزى،

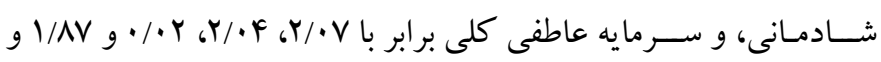

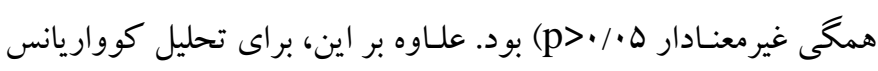
جندمتغيرى، نتايج آزمون باكس براى بررسى بر ابرى ماتريس كوواريانس

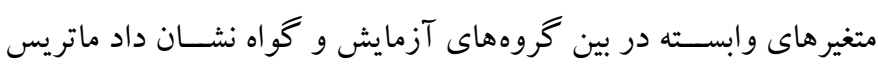

جدول 0: نتايج تحليل كوواريانس تكمتغيرى سرمايه عاطفى كلى

\begin{tabular}{|c|c|c|c|c|c|c|c|c|}
\hline توان آزمون & اندازه اثر & معنادارى & Tاره F F & ميانكين مجذورات & درجه آزادى & مجموع مجذورات & منبع تغييرات & متغير \\
\hline 1 & $\cdot / \wedge 9$ &.$/ . \cdot 1$ & $r r \cdot / r$ & $9 V r 9 / 90$ & 1 & $9 V \times 9 / 90$ & ي يش آزمون & \multirow{3}{*}{ سرمايه كلى } \\
\hline 1 & $\cdot / V \Delta$ & $\cdot / \cdot \cdot 1$ & $9 \mathrm{~s} / \cdot \mathrm{V}$ & rrT/Ir & r & $r 90 \cdot / r 9$ & گروه & \\
\hline- & - & - & - & $r Y / \cdot 1$ & \&l & $\wedge 91 / 4 Y$ & خطا & \\
\hline
\end{tabular}

است. براى بررسى تفاوت كروهها در مؤلفههاى سرمايه عاطفى، از تحليل كوواريانس جندمتغيرى اسـتفاده شـد. نتايج آزمون نشـان داد كه بين سه

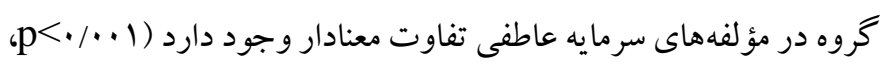
A كوواريانس جندمتغيرى در مورد مؤلفههاى ســـرمايه عاطفى ارائه شــــه
همانطور كه در جدول f مشـاهده مىشـود، در سرمايه عاطفى كلى

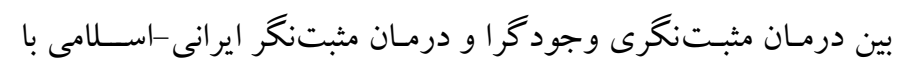

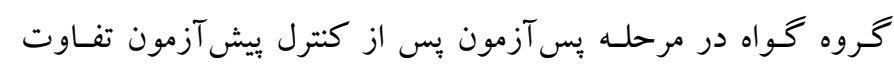

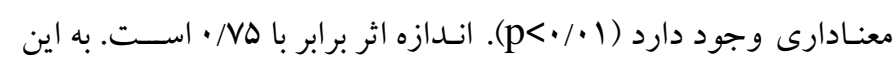
معنى كه تحليل كوواريانس تككمتغيرى با · · ا درصـد توان، له درصــ تفـاوت در ســرمـايسه عـاطفى كلى بين كروههاى يثزوهش را تأييد كرده

است.

جدول ا: نتايج تحليل كوواريانس جندمتغيرى مؤلفههاى سرمايه عاطفى

\begin{tabular}{|c|c|c|c|c|c|c|c|c|}
\hline توان آزمون & اندازه اثر & معنادارى & Tماره F & ميانكين مجذورات & درجه آزادى & مجموع مجذورات & منبع تغييرات & متغير \\
\hline 1 & .194 &.$/ \cdot 1$ & $M r / v q$ & YMN/VG & $r$ & $\Delta V V / \Delta F Y$ & كروه & \multirow{2}{*}{ عاطفه مثبت } \\
\hline- & - & - & - & $N / \Delta F$ & rq & (MTr/19 & خطا & \\
\hline.$/ 99$ & $\cdot|4|$ &.$/ . \cdot 1$ & $1 r / r q$ & $V \Delta / \Delta I$ & r & $101 / .1$ & گروه & \multirow{2}{*}{ احساس انرزى } \\
\hline - & - & - & - & $\Delta / 94$ & ma & rla/Ar & خطا & \\
\hline 1 & $\cdot / \Delta r$ &.$/ . \cdot 1$ & $r \mid / v q$ & $\wedge \& / \wedge 9$ & r & $I V T / V A$ & كروه & \multirow{2}{*}{ شادمانى } \\
\hline - & - & - & - & $r / 99$ & rq & $1 \Delta \Delta / \Delta r$ & خطا & \\
\hline
\end{tabular}

اثر برابر با |F/ • اســته، به اين معنى كه أ| درصسـ تفاوت در احســاس انرزى بين كروههاى يزوهش تأييد شـده اسـت. در شادمانى نيز اندازه اثر برابر با سه/ • اسـت، به اين معنى كه سه درصـد تفاوت در شـادمانى بين كروههـاى يثزوهش مرود تـديــ قرار كرفته اســت. در جـدول V نتايج آزمون تعقيبى بونفرونى براى تعيين تفــاوت دو بـه دو كروههاى بزّوهش در سرمايه عاطفى و مؤلفههاى آن ارائه شده است.
همانطور كه در جدول 9 مشاهده مىشود، در عاطفه مثبت، احساس انرزى، و شـادمـانى بين درمـان مثبتنكرى وجود كرا و درمان مثبتنگر

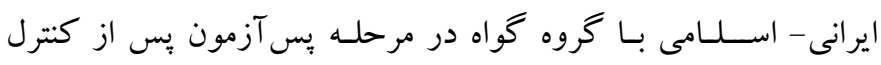

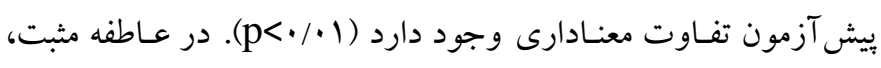
اندازه اثر برابر با سو/ • است، به اين معنى كه سو درصد تفاوت در عاطفه مثبت بين كروههاى يثزوهش تأييد شـده اسـت. در احساس انرزى، اندازه 
جدول Ү: نتايج آزمون تعقيبى بونفرونى در سرمايه عاطفى و مؤلفههاى آن

\begin{tabular}{|c|c|c|c|c|c|}
\hline معنادارى & خطاى استاندارد & تفاوت ميانكينهاى تعديلشده & كروه مورد مقايسه & كروه مبنا & متغير \\
\hline.$\cdots 1$ & $1 / 14$ & $-\Lambda / k \mu$ & كروه مثبتنگرى وجود كرا & كروه گو اه & \multirow{3}{*}{$\begin{array}{l}\frac{9}{3} \\
-3 \\
3\end{array}$} \\
\hline.$/ \cdots 1$ & $1 / 10$ & $-V / 91$ & گروه مثبتنخرى ايرانى - اسلامى & كروه گواه & \\
\hline 1 & $1 / 11$ & $\cdot / \Delta r$ & كروه مثبتنخرى ايرانى - اسلامى & گروه مثبتنگرى وجود كرا & \\
\hline.$/ \cdot 1$ & $\cdot / 94$ & $-F / 94$ & خروه مثبتنگرى وجودمرا & كروه گُواه & \multirow{3}{*}{$\begin{array}{c}\overline{3} \\
3 \\
\overline{3} \\
\bar{y} \\
\bar{y}\end{array}$} \\
\hline.$\cdots 1$ & . /9r & $-r / Y q$ & گروه مثبتنخرى ايرانى - اسلامى & كروه گو اه & \\
\hline 1 & $\cdot / 9$ & $1 / \pi v$ & گروه مثبتنخرى ايرانى - اسلامى & خروه مثبتنخرى وجود خرا & \\
\hline.$\cdots 1$ & $\cdot / \mathrm{W}$ & $-F / 9 \Delta$ & گروهه مثبتنخرى وجود گكرا & گروه گو اه & \multirow{3}{*}{$\frac{\sqrt[3]{3}}{3}$} \\
\hline.$/ \cdots 1$ & $\cdot / \mathrm{va}$ & $-r / 99$ & گروه مثبتنكرى ايرانى - اسلامى & كروه كو اه & \\
\hline 1 & $\cdot / V^{9}$ & $1 / Y 9$ & گروه مثبتنخرى ايرانى - اسلامى & كروه مثبتنگرى وجود كرا & \\
\hline.$/ \cdots 1$ & $1 / 11$ & $-\mid N / \cdot \Delta$ & گروهه مثبتنخرى وجود گرا & گروه گو اه & \multirow{3}{*}{$\begin{array}{c}3 \\
3 \\
3^{2} \\
\frac{9}{3} \\
-3\end{array}$} \\
\hline$\cdot / \cdots 1$ & l/AF & $-\mid f / \wedge q$ & گروه مثبتنغرى اير انى - اسلامى & گروه گواه & \\
\hline 1 & $1 / W$ & $r / 10$ & گروه مثبتنغرى ايرانى - اسلامى & كروه مثبتنگرى وجود كرا & \\
\hline
\end{tabular}

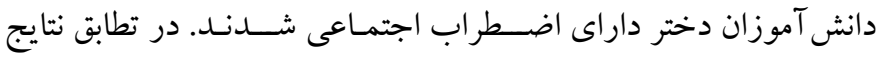
يثزوهش حاضر با يثوهش هاى مشابه، اگرجّه به دليل نوين بودن دو درمان مورد اسـتفاده در يزوهش و متغير سـرمايه عاطفى، ئزوهشى در دسـترس قرار نكرفـت كـه بهطور كامل از لحاظ موضــوعى با اين بزظوهش تطابق داشـته باشـد، ولى با حفظ جهت كيرى كلى مثبت نكرى يزوهش حاضر، مى توان كفت كه نتايج حاصل از اين يثوهش با يافتهاى مطالعات داخل ايران، مانند مطالعه فرنام و مددىزاده مبنى بر تأثير آموزش مثبتنگرى بر افزايش خلق مثبـت و شــادمـانى (IF)؛ بـا نتـايج مطـالعـه هنرمندزاده و ســـاديان مبنى بر تأثير مداخله مثبت نكر گروهى بر افزايش شــادمانى (ها)؛ با مطالعه نوفرسـتى و همكاران مبنى بر تأثير رواندرمانى مثبتنگر بر شـادمانى افراد داراى نشـانهاى افسـردكى (19)؛ و با نتايج مطالعات خـارج از ايران نظير مطـالعه راث و همكـاران (IV) مبنى بر تـأثير درمان مثبـتنكر بر افزايش بهزيســتى ذهنى نو جوانـان؛ بـا فراتحليـل ســين و

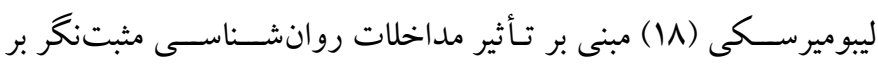
افزايش بهزيسـتى و شـادزيسـىى؛ با فراتحليل رشـيد و انجم (19) مبنى بر تـأثير برنـامـههـاى درمـانى مثبـتنكر بر افزايش عملكرد و رضــايـت از خويشــن، و بـا مطالعه ســليخمن و همكاران (·r) مبنى بر تأثير مداخله مثبتنكر در افزايش نشاط و شادمانى و كاهش علائم افسردگى، همسويى دارد. تفاوت اصسلى بين نتايج يثوهش حاضسر با نتايج بثزوهشهاى مورد
همانطور كه در جدول V مشاهده مى شود، در عاطفه مثبت، احساس انرزى، شـادمانى، و سرمايه عاطفى كلى بين درمان مثبتنكرى وجودگرا و درمان مثبتنگر ايرانى - اسـلامى با گروه گو اه تفاوت معنادارى وجود

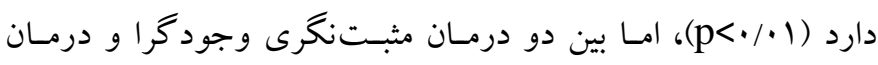
مثبـتنكر ايرانى - اســلـامى بـا يكـديخر تفـاوت معنـادارى وجود ندارد

$\cdot(\mathrm{p}>\cdot / \cdot \Delta)$

\section{بحث و نتيجه تيرى}

اين بزووهش كه با هدف بررسى اثربخشى درمان مثبتنگرى وجودگر او و درمان مثبت نكر اير انى -اسـلامى بر سـرمايه عاطفى و سـه مؤلفه آن شامل عـاطفـه مثبـت، احســاس انرزى، و شــادمانى دانش آموزان دختر داراى اضـــر اب اجتمـاعى انجـام شـــ، از اثربخشـى هر دو نوع درمان نوين وجود گرايى مثبتنكر و درمان مثبتنكر ايرانى - اسـلامى حمايت كرد.

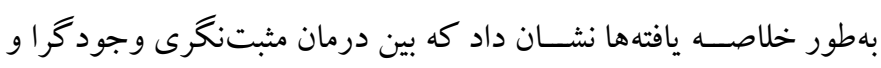
درمان مثبتنگ اير انى - اسـلامى با گرووه گو اه در سـرمايه عاطفى و سـه مؤلفـه آن در يس آزمون يس از كنترل ييش آزمون تفـاوت معنـادارى و جود دارد، اما بين دو درمان با يكديخر تفاوت معنادارى به دست نيامد. در مجموع نتايج نشـان داد كه اين دو شـيوه درمان نسـبت به گرووه گو اه بـهـور معنـادارى موجـبـ افزايش ســـرمـايـه عاطفى و مؤلفههاى آن در 
اهـداف مبتنى بر ترس و نـاتوانى، بر معنـا و اهــاف مبتنى بر قوت و

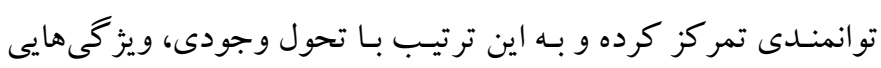

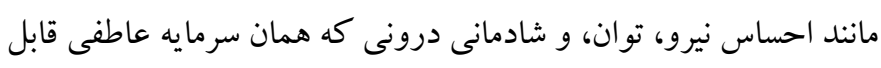

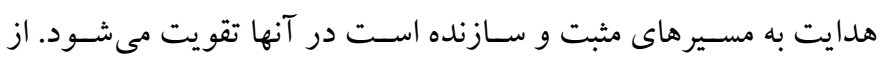

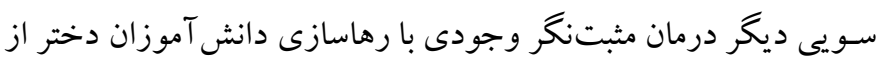

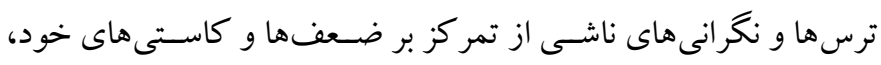

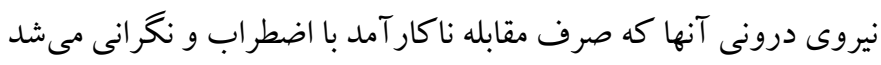
را آزاد سـاخته و به اين ترتيب سطح سرمايه عاطفى آنها را افزايش دادو داده

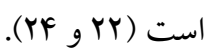

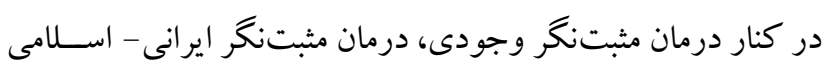

نيز در يزوهش حاضر نشان داد كه با تمر كز بر خوشينى، اميد، تو كل به

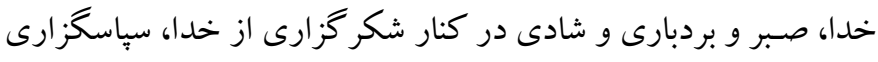

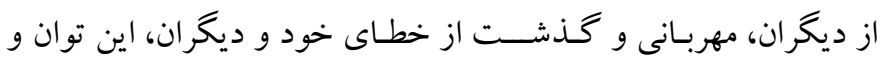

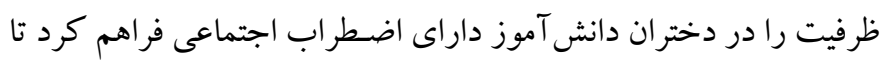

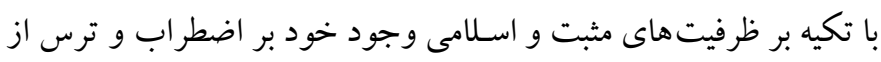
موقعيت هاى اجتماعى غلبه كرده و با سـرمايه عاطفى بالاتر به ادامه مسيرير

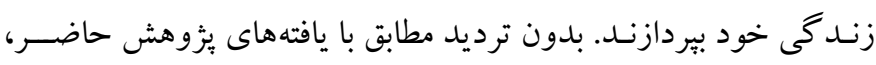

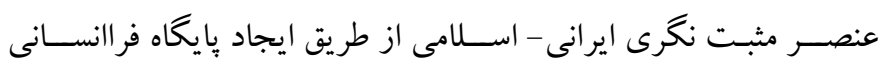

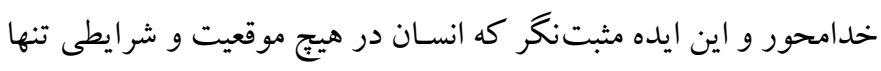

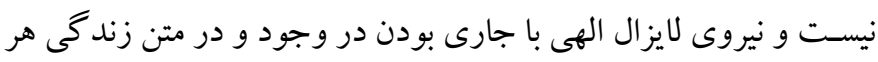
انسانى مى تو اند نيرو و توان عاطفى وى را به مسير تعالى و شكوفايى بيشتر

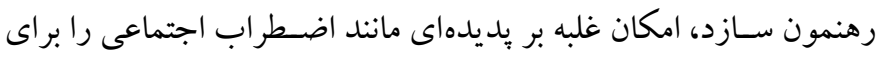

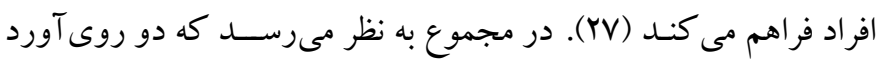

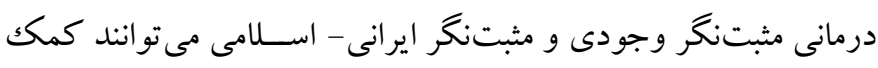

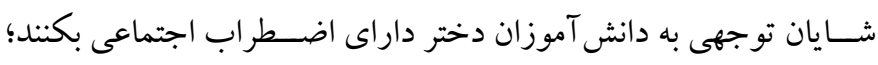

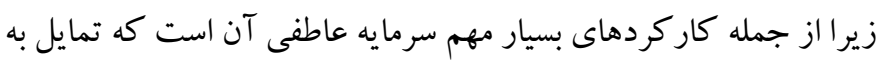

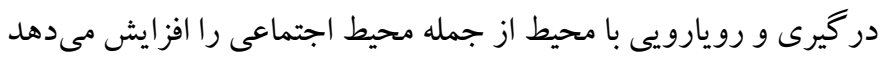

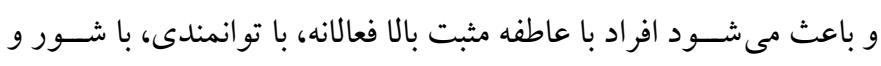

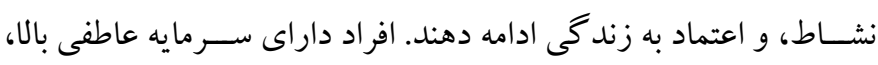

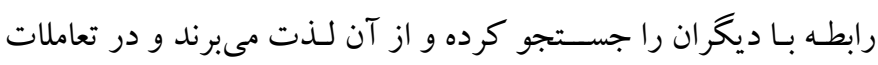

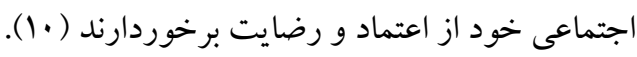

اشـاره در اين اسـت كه در مطالعه حاضر نسبت به مطالعات قبلى، سرمايه عاطفى و سـه مؤلفه آن همزمان بهعنوان متغير وابسـته همر اه با دو درمان

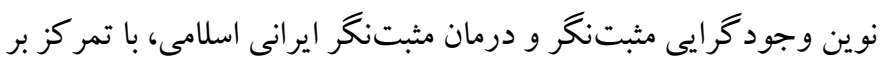

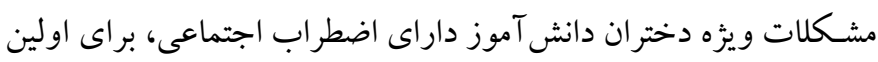
بار به مرحله اجرا در آمده است.

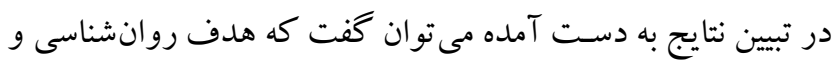

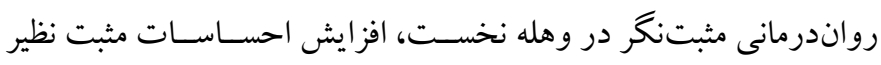

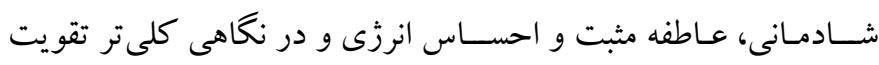

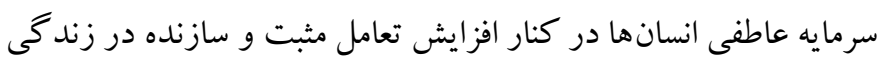
و بهزيستى روانشناختى است. مداخلات روانشناسى مثبت با وجود اين

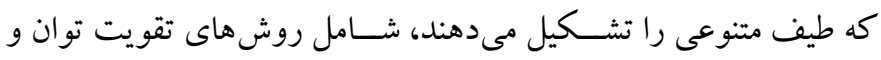

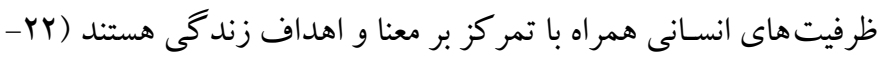

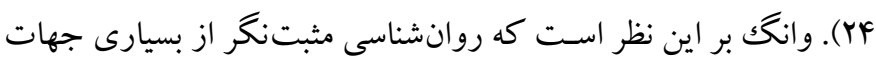

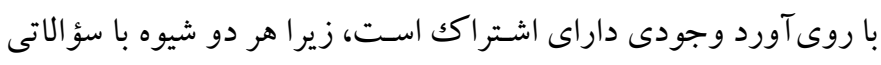

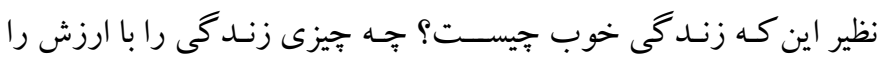

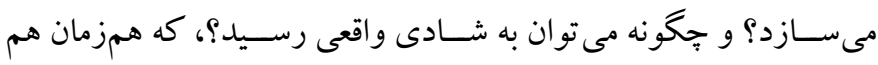

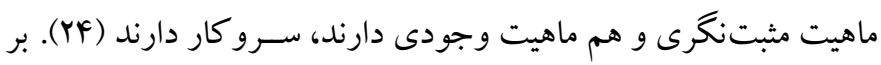

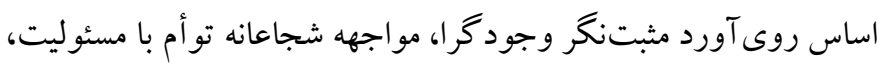

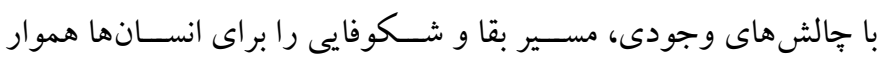

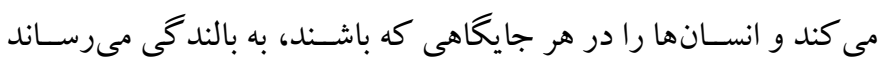

در اين بثزوهش نيز، تمر كز در درمـان مثبـتنكر وجود گرا بر تقويت

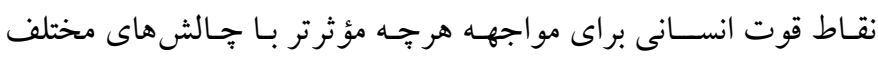

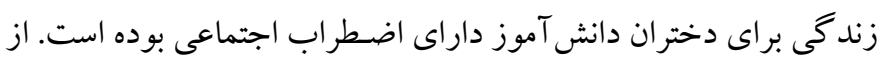

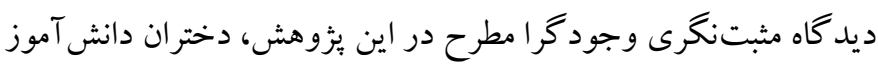

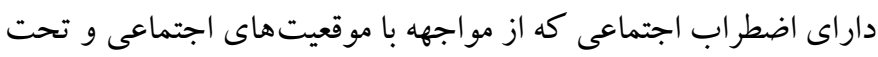

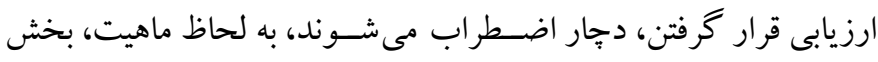

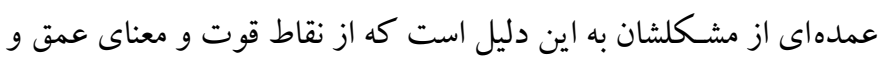

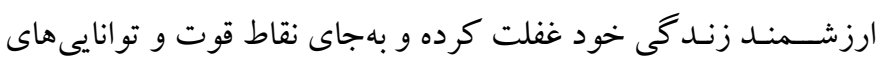

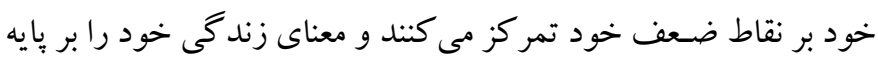

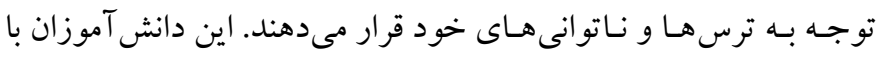

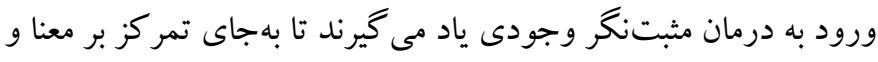


ايرانى - اسـلامى اسـتفاده شــده در اين مطالعه، بهره ببرند. علاوه بر اين

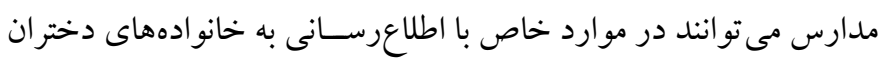

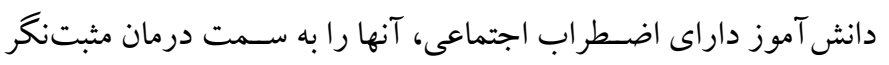

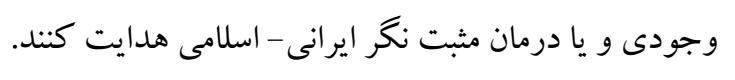

تشكر و قدردانى: اين يُرهش منتج از رساله دكتراى روانشناسى خانم سارا

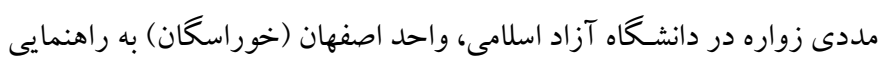

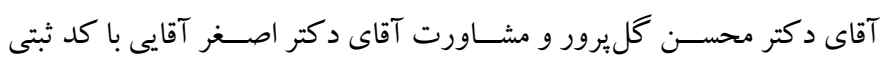

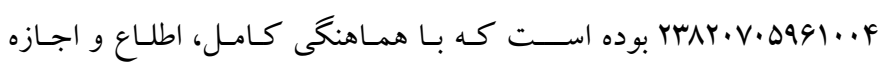
Tموزشويرورش شهر اردستان طى شماره نامه \&

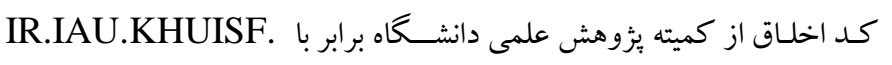

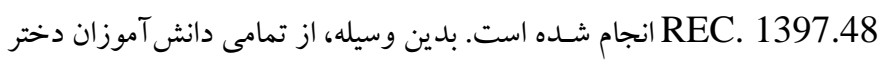

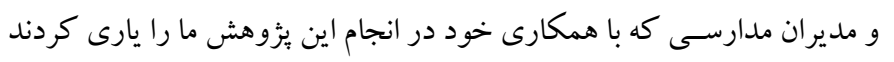

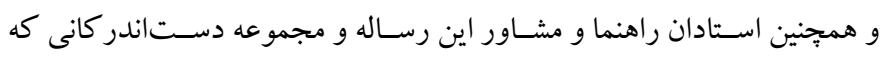

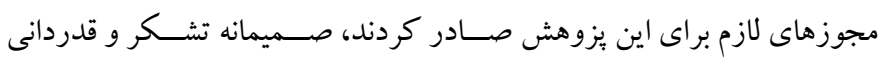
مى كنيم. تضاد منافع: اين يزوهش بدون حمايت هيج سازمانى انجام شده و نتايج آن با

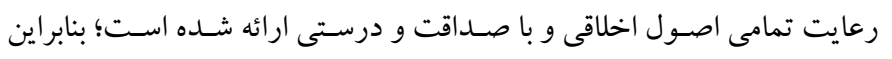

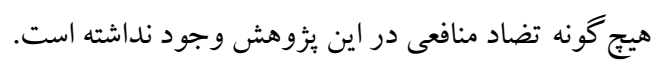

در بايان بحث نيز للازم است تا توجه جامعه علمى را به محدوديتهاى

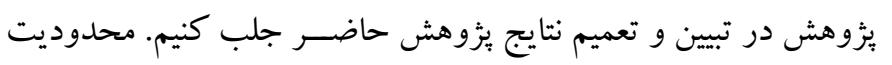

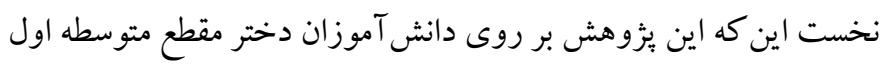

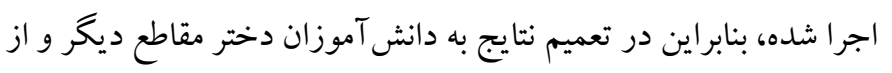

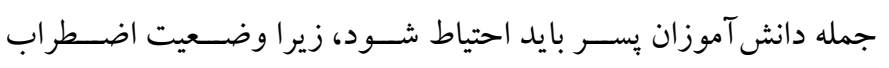

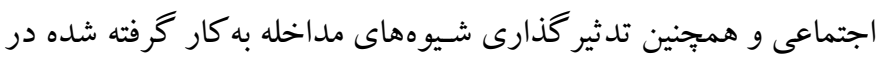

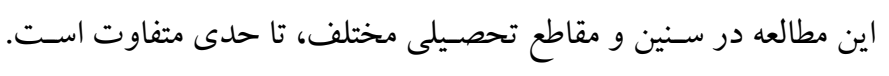

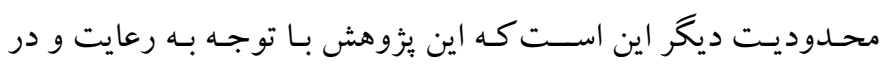

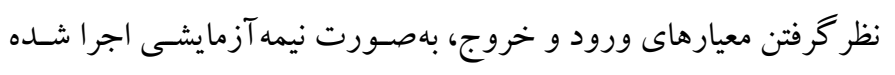

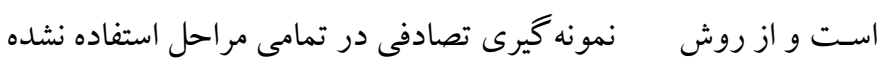

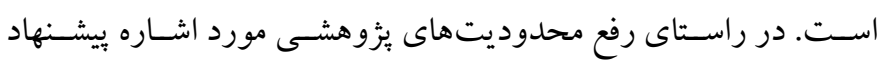

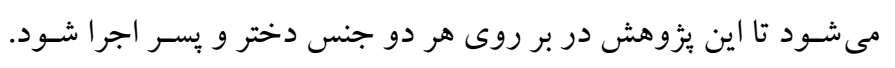

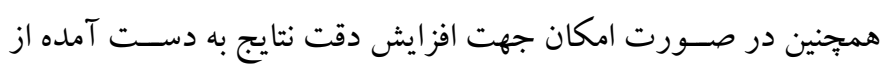

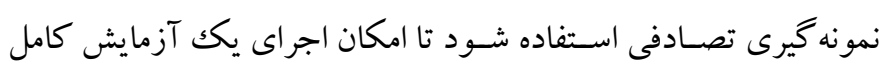

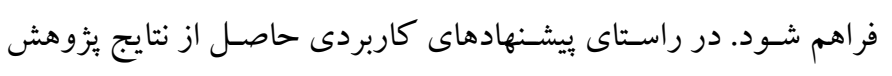
حاضر، توصيه مى شود كه مدارس مقطع متوسطه با استفاده از مشاوران و

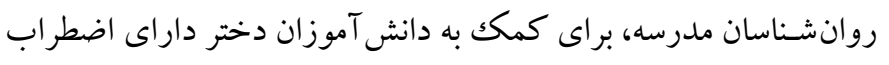

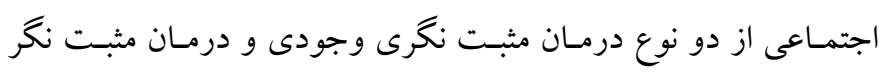




\section{References}

1. Asakura S. Diagnosis and treatment of social anxiety disorder. Seishin Shinkeigaku Zasshi. 2015; 117(6): 413-430. [Link]

2. American Psychiatric Association. Diagnostic and statistical manual of mental disorders (DSM-5). Fifth edition. Washington DC: American Psychiatric Association; 2013, pp: 111-131. [Link]

3. Cruz ELD da, Martins PD de C, Diniz PRB. Factors related to the association of social anxiety disorder and alcohol use among adolescents: a systematic review. J Pediatr (Rio J). 2017; 93(5): 442-451. [Link]

4. Alkozei A, Cooper PJ, Creswell C. Emotional reasoning and anxiety sensitivity: associations with social anxiety disorder in childhood. J Affect Disord. 2014; 152-154: 219-228. [Link]

5. Bandelow B, Michaelis S. Epidemiology of anxiety disorders in the 21st century. Dialogues Clin Neurosci. 2015; 17(3): 327-335. [Link]

6. Zarafshan H, Mohammadi MR, Salmanian M. Prevalence of anxiety disorders among children and adolescents in Iran: A systematic review. Iran J Psychiatry. 2015; 10(1): 1-7. [Link]

7. McAleavey AA, Castonguay LG, Goldfried MR. Clinical experiences in conducting cognitive behavioral therapy for social phobia. Behav Ther. 2014; 45(1): 21-35. [Link]

8. Dryman MT, Gardner S, Weeks JW, Heimberg RG. Social anxiety disorder and quality of life: How fears of negative and positive evaluation relate to specific domains of life satisfaction. J Anxiety Disord. 2016; 38: 1-8. [Link]

9. Hofmann SG, Wu JQ, Boettcher H. Effect of cognitive behavioral therapy for anxiety disorders on quality of life: a meta-analysis. J Consult Clin Psychol. 2014; 82(3): 375-391. [Link]

10. Enayati M, Golparvar M. The relationship between affective-collective investment with psychological wellbeing due to the role of affective capital among nurses. Management Strategies in Health System. 2018; 3(1): 69-79. [Persian]. [Link]

11. Karowski L, Garratt GM, Ilardi SS. On the integration of cognitive-behavioral therapy for depression and positive psychology. J Cogn Psychother. 2006; 20(2): 159-170. [Link]

12. Seligman MEP, Csikszentmihalyi M. Positive psychology: An introduction. Am Psychol. 2000; 55(1): 5-14. [Link]
13. Seligman MEP, Rashid T, Parks AC. Positive psychotherapy. Am Psychol. 2006; 61(8): 774-788. [Link]

14. Farnam A, Madadizade T. Effect of positive training on positive psychological states (character strengths) of female high school students. Positive Psychology Research 2017; 3(1):61-76. [Persian] [Link]

15. Honarmand Zadeh R, Sajjadian I. Effectiveness of positive group intervention on psychological wellbeing, resiliency and happiness of foster care adolescent girls. Positive Psychology. 2016; 2(2): 3550. [Persian]. [Link]

16. Noferesty A, Roshan R, Fata L, Hassan Abadi HR, Pasandideh A, Shaeiri mohhamad R. The effectiveness of positive thinking intervention program on happiness and irrational beliefs of delinquent adolescents M. Positive Psychology. 2015; 1(1): 1-18. [Persian]. [Link]

17. Roth RA, Suldo SM, Ferron JM. Improving middle school students' subjective wellbeing: efficiency of a multicomponent positive psychology intervention targeting small groups of youth. School Psych Rev. 2017; 46(1): 21-41. [Link]

18. Sin NL, Lyubomirsky S. Enhancing well-being and alleviating depressive symptoms with positive psychology interventions: a practice-friendly metaanalysis. J Clin Psychol. 2009; 65(5): 467-487. [Link]

19. Rashid T, Anjum A. Positive psychotherapy for young adults and children. In: Abela JRZ, Hankin BL, editor. Handbook of depression in children and adolescents. New York, NY, US: Guilford Press; 2008, pp: 250-287. [Link]

20. Seligman MEP, Parks AC, Steen T. A balanced psychology and a full life. Philos Trans R Soc Lond B Biol Sci. 2004; 359(1449): 1379-1381. [Link]

21. Alfano CA, Beidel DC, Turner SM. Cognitive correlates of social phobia among children and adolescents. J Abnorm Child Psychol. 2006; 34(2): 182-194. [Link]

22. Wong PTP. Meaning therapy: an integrative and positive existential psychotherapy. J Contemp Psychother. 2010; 40(2): 85-93. [Link]

23. Passmore H-A, Howell AJ. Eco-existential positive psychology: experiences in nature, existential anxieties, and well-being. J Humanist Psychol. 2014; 42(4): 370-388. [Link]

24. Hoffman, L., Vallejos, L., Cleare-Hoffman, H. P., \& Rubin, S. Emotion, relationship, and meaning as core existential practice:

foundations. Journal of Contemporary Psychotherapy, 1-10. [Link] 
25. Jamshidian QalehShahi P, Aghaei A, Golparvar M. Comparing the effect of Iranian positive therapy and acceptance -commitment therapy on depression, anxiety and stress of infertile women in Isfahan city. Journal of Health Promotion Management. 2017; 6 (5): 8-16. [Persian]. [Link]

26. Taha AA, El-shereef EA, Abdullah TIM, Abdullah RIM, Aldahasi WAM. Social anxiety disorder and its correlates among female students at Taif University, Saudi Arabia. Research in Psychology and Behavioral Sciences. 2017; 5(2): 50-56. [Link]

27. Ebrahiminejad S, Poursharifi H, Bakhshiour Roodsari A, Zeinodini Z, Noorbakhsh S. The effectiveness of mindfulness-based cognitive therapy on Iranian female adolescents suffering from social anxiety. Iran Red Crescent Med J. 2016; 18(11): e25116. [Link]
28. Connor KM, Davidson JR, Churchill LE, Sherwood A, Foa E, Weisler RH. Psychometric properties of the Social Phobia Inventory (SPIN). New self-rating scale. Br J Psychiatry. 2000; 176: 379-386. [Link]

29. Mokhber Dezfooli A, Rezaee M, Ghazanfari F, Mirdrikavand F, Gholamrezae S, Moazzeni T, et al. Modeling of social phobia according to emotional and cognitive components and gender: applying of path analysis. Journal of Psychological Studies. 2015; 11(3): 29-52. [Persian]. [Link]

30. Golparvar M, Zareiy M. The effect of job success training on affective capital and flow at work in Hemophilic patients. Journal of Health Based Research. 2018; 3(4): 309-322. [Persian]. [Link] 